\title{
Haurtzaroko esperientzia gogor goiztiarren ondorioz trauma-egoeran egon daitezkeen ikasleenganako hurbilpena
}

\section{Iker Sistiaga Gaztañaga}

Bilboko Irakasleen Unibertsitate Eskola, Euskal Herriko Unibertsitatea UPV/EHU

\section{Gema Lasarte Leonet}

Ikerketa Hezitzaile (Ikhezi) ikerkuntza talde kontsolidatua, Euskal Herriko Unibertsitatea UPV/EHU

gema.lasarte@ehu.eus

Ikasle bakoitzak bere ikasketa-prozesua baldintzatzen duten gaitasun, interes, erritmo, motibazio eta esperientzia ezberdinak ditu, eta azken hauen artean kokatzen dira Adverse childhood experiences (ACE), euskarara "haurtzaroko esperientzia gogor goiztiar” gisa itzuliko duguna. Esperientzia hauek (abusua, abandonua edo etxeko desegituraketak) eragin zuzena dute ikasleen garapen integralean, ondorio negatibo ugari eraginez. Hortaz, lan honen helburu nagusia eskolek eta irakasleek gaiari buruz dakitena eta horren inguruan egiten dutena eta adituek diotena alderatzea izan da, egoera honetan dauden ikasleei behar duten laguntza eman ahal izateko gakoak bilatu nahian. Erabili den metodologia kuantitatiboaren eta kualitatiboaren nahasketa izan da. Ondorioetan, sentsibilitatea eta esperientzia azaltzen dira gako gisa.

\section{GAKO-HITZAK:}

Haurtzaroko esperientzia gogor goiztiarrak, haurtzaroa, abusua, abandonua, familian emandako disfuntzioak, atxikimendua, erresilientzia.
Cada alumno tiene diferentes capacidades, intereses, ritmos, motivaciones y experiencias que condicionan su proceso de aprendizaje. Adverse childhood experiences (ACE), que traduciremos al castellano como "experiencias adversas en la edad temprana", hace referencia a todo tipo de abuso, abandono o desestructuración del hogar sufrido por los menores de 18 años y que afecta a su óptimo desarrollo integral. El principal objetivo de este trabajo ha sido comparar lo que las escuelas y los profesores saben y hacen al respecto de este tema y lo que los expertos recomiendan, con la finalidad de hallar aquellas claves que nos faciliten dotar a estos alumnos de la ayuda necesaria. La metodología que se ha utilizado es una metodología mixta entre la cualitativa y la cuantitativa. Las conclusiones apuntan como claves a tener en cuenta la sensibilidad y la experiencia.

\section{Palabras Clave:}

Experiencias adversas en la edad temprana, infancia, abuso, abandono, disfunciones en el hogar, apego, resiliencia. 


\section{Sarrera}

Hezkuntzak duen helburu nagusia ikasle guztien gaitasunen garapena eta edukien bereganatzea da, beraien testuinguru soziokulturalean modu aktiboan parte-hartzeko gai izan daitezen. Hau lortu ahal izateko, eskolak hezkuntza ulergarri eta, aldi berean, askotarikoa eskaintzea ezinbestekoa du; diskriminazioa eta ezberdintasunak saihesten dituen kultura eskainiz eta, aldi berean, norbanakoaren ezaugarri eta beharrak errespetatuz. Baina, hau horrela dotore geratzen bada ere, irakasleria formatua al dago egun jendarteak bizi duen aniztasun egoerari aurre egiteko? Nondik abiatu beharko luke hurbilpen honek? Horiek dira luze zabal marko teoriko nahiz enpirikoaren bidez artikulu honek erantzun nahi izango dituen galdera nagusiak.

Badira ikasle guztiek partekatzen dituzten hezkuntza-behar batzuk, euren garapen pertsonal eta sozializazioari erreferentzia egiten diotenak, curriculumean zehaztuta daudenak. Hala ere, ikasle guztiek ez diote curriculumean zehaztutako eduki horiei modu berean aurre egiten, norbanako bakoitzak bere ikaspen-prozesua baldintzatzen duten gaitasun, interes, erritmo, motibazio eta esperientzia ezberdinak ditu eta. Azken hauek dira, hain zuzen ere, ikasle bakoitza bakarra eta errepikaezina bihurtzen dutenak. Eta gaitasun horien kudeaketa okerrean leudeke, gutxien ikertu diren irakats prozesuak, hain zuzen ere, ikasleak eskolatik harrera-etxeetara eta handik kartzelatarako bidean jartzen dituenak.

Zentzu honetan, aniztasunaren kontzeptuak ikasle bakoitzak berezko hezkuntza-behar zehatzak dituela ematen du aditzera, zeinak ase ahal izateko laguntza pedagogiko indibidualizatua eskaintzea izango litzatekeen hezkuntza sistemak duen tresnarik nagusiena. Hala eta guztiz ere, ikasle guztien beharrak ez dira bereziak, badaude aniztasunari aurre egiteko irakasle guztiek ezagutzen dituzten jokabideak: hala nola, denbora gehiago eskaintzea, estrategia edota material ezberdinak erabiltzea edo jarduera osagarriak diseinatzea, besteak beste.

Zenbait kasutan, ordea, aipatutako behar horiek osatu ahal izateko laguntza, baliabide eta eskuartze pedagogiko bereziak abian jartzea beharrezkoa da. Behar bereziak dituzten ikasleei buruz hitz egiten ari gara, eta egoera hauek bideratu ahal izateko, curriculum-egokitzapenak eta ikaslearen testuinguru sozioemozionalari arreta berezia eskaintzea dira ikastetxeak balia ditzakeenak (Warnock in Blanco, 1999).

Duela gutxi arte desgaitasunen bat zuten ikasleek soilik jasotzen zituzten gisa honetako laguntza eta baliabide bereziak, ikaskuntza zailtasunak zituzten beste askok inongo laguntzarik gabe jarraitzen zuten bitartean. Hezkuntza-behar bereziak kontzeptuak ikaskuntza zailtasunak dituen edozein ikaslek behar dituen laguntza eta baliabide bereziak jasotzea dakar, modu iragankor edota iraunkorrean, ahalik eta testuinguru normalizatuenean.
Sarrera honetan zertzelada teoriko batzuk eman ostean, kontzeptualizazioa garatze aldera, lehenik, adverse childhood experience (ACE) kontzeptua ${ }^{1}$, eta bigarrenik, atxikimendua nahiz erresilientzia landuko dira. Behin kontzeptualizazioa garaturik, lan honen helburuak eta metodologia zehaztuko dira eta lan enpirikoa egingo da. Lan enpirikoak eremu teorikoan esandakoa ulertzea eta esplikatzea izango du helburutzat. Horretarako, ikastetxe bateko irakasleen artean inkesta bat egin da gai honen inguruan duten sentsibilitatea hautemateko eta, ondoren, gai honen inguruan group focus bat egin da hainbat gogoeten inguruan sakontzeko.

\section{Marko teorikoa}

\subsection{Arrisku-egoeran dauden ikasleak antzeman nahian}

Gaur egun badakigu ikasgeletan zailtasunak iturri ezberdinetatik datozkien ikasleak topa daitezkeela, hala nola, euren historia pertsonalak, hezkuntzakoak edota izandako esperientzia ezberdinek behar bezala garatzen edota sozializatzen ez utzitakoak. Gainera, bazterreko testuinguruetatik datozenak edota ikastetxea kokatuta dagoen tokikoa ez den etnia edota kultura ezberdineko ikasleak ere topa daitezke, zeintzuek haien ezaugarri sozial eta kultural bereizgarriak kontuan hartzen ez dituzten eskoletan egokitzeko zailtasunak izan ditzaketen (Blanco, 1999).

Gómez Montesek (2005) eskoletan dagoen aniztasuniturrien zerrenda luzea aipatu ondoren (gaitasun, motibazio, prestakuntza edota ikasteko modu ezberdinak, familia-egoera, ingurune soziokulturala, migrazio-prozesuak, hizkuntzarekiko zailtasunak, eskola-uztea edota absentismoa, etorkizunarekiko itxaropenak, etab.), egoera ezberdin horiek guztiak bildu ahal izateko, bi faktore nagusiren inguruan sailkatzeko proposamena luzatzen du.

Alde batetik, esparru soziologikoarekin lotura duten faktoreak izango genituzke kontuan. Herrialde baten testuinguru ekonomiko eta soziokulturaletik esan nahi da (familia ikuskeran, bizitzan, aisialdian, garapen teknologikoan, migrazio prozesuetan eta abarretan izandako aldaketak) eta baita izaera geografiko, etniko eta erlijiosotik eratorriak direnak, hauek ere gizartearen, eta ondorioz, hezkuntza sistemaren aniztasuna areagotzen dute eta.

Bestetik, esparru kognitiboarekin lotura duten faktoreak antzemango genituzke, hala nola, ikasle bakoitzaren gaitasun intelektualen arteko ezberdintasun gaindiezinetatik (guztiek ez dute ez modu ez erritmo berean ikasten), ikaskuntzarekiko motibaziotik, interes akademiko zein profesionaletik, irakasteko eta ikasteko estilo ezberdinetatik eratorriak direnak.

${ }^{1}$ Guk euskaraz "haurtzaroko esperientzia goiztiar gogorrak" bezala definitu dugu, nahiz eta adverse childhood experience terminoa erabili. 
Jadue-k (2002) zailtasunak dituzten ikasleei buruz hitz egiteko orduan, beste koska bat gehitzen dio eta "arrisku-egoeran dauden ikasleak" kontzeptua erabiltzen du; arriskuan egotea eragiten duten faktoreak urritasun kognitiboa eta hizkuntzakoa, arreta galkorra, harremanetarako gaitasun eskasa eta jokaera eta emozioekin loturiko zailtasunak direla zehaztuta.

Jokaera eta emozioekin loturiko faktoreen ildoari jarraituz, gaur egun, errendimendu akademiko baxua eta portaera- eta emozio-asaldurak azaltzen dituzten ikasle ugari daude ikasgeletan, eta askok ez dute behar duten laguntza profesionala jasotzen, ez eskolan ezta bertatik kanpo ere. Honek ondorioak dakartza. Izan ere, zailtasun hauek ez tratatzeak ikasle horiengan ikaskuntza-arazoak eragiteaz gain, irakaslearen irakasteko eta beraien kideen ikasteko gaitasunean eragiten du, irakasle askorengan egoerak gainditzen dituenaren goganbeharra sentiaraziz.

Kontuan izan behar da ikasle bakoitzak bere ezaugarri bereizgarriak dituela alderdi kognitiboan, afektiboan eta baita portaeran ere, baina, tamalez, eskolek ikasle "normalei” bideratutako irakaskuntza eskaintzen dutela, hau da, errendimenduan eragiten dieten zailtasun, urritasun edota gabeziarik adierazten ez dutenentzat ari direla. Ondorioz, "normaltasun" horretan kokatzen ez diren ikasleek errendimendu baxua, eta kasu larrienetan, eskolaporrota jasateko arriskua dute (Jadue, 2002).

Ikasleak “arrisku-egoeran” kokatzen dituzten egoera eta arrazoien banakako analisian sartu aurretik, orain arte hainbeste aldiz erreferentzia egindako "errendimendu akademikoa" kontzeptua bibliografian nola ulertzen den eta ikasleen testuinguruak harekin duen erlazioa azalduko da.

Errendimendu akademikoa "adin eta maila akademikoari dagozkion edukien inguruan adierazitako ezagupen-maila da" (Jiménez in Navarro, 2003: 2). Definizio honek, ordea, ikasleen errendimendua ebaluazio prozesuen bidez soilik egitera mugatzen du, baina metodologia hau ez da nahikoa hezkuntzaren kalitatea hobetzeko. Hala eta guztiz ere, era honetara lan egin nahi izanez gero, ezinbestekoa da, ikasle bakoitzaren banakako lana ebaluatzeaz gain, testuinguruak berarengan duen eragina kontuan izatea (Navarro, 2003).

Izan ere, asko dira ikasleen arrakasta edo porrot akademikoan eragiten duten faktoreak. Hala ere, hiru kategoriatan elkar ditzakegu: a) faktore psikologikoak (inteligentzia emozionala, pertsonalitatea, motibazioa, etab.); b) faktore soziologikoak edo testuingurukoak (klima soziala, eskola-klima, familia-giroa etab.); c) faktore didaktiko edo pedagogikoak (irakaskuntzametodoak, baliabide didaktikoak, etab.) (GonzálezTorres eta Tourón, 1992).

Aipatutako ikasle hauek "gatazkatsu" gisa izendatu ohi dira, edozein irakats saio beste modu batera planteatzea eskatuko dutenak; edonori (ikasle, irakasle, zuzendari eta, zenbait kasutan, poliziari) aurre emateko gai direnak, azkenik, irakasleek haietaz ezer jakin nahi ez dutelarik. Kasu hauek aztertzean konturatzen gara jokabide hauen iturria haurrak zirenetik bizi izandako familia ezegonkortasuna dela kasu askotan, haurtzaroko abusu-egoera, abandonu nahiz familia-disfuntzioen ondorioz (Garai et al., 2019).

Orain arte aipatutako ikasle "gatazkatsu" hauetatik gehienek haurtzaroan esperientzia gogorrak bizi izan dituzte (Perry et al., 1995). Haurtzaroan bizitako egoera gatazkatsu izenarekin ezagutzen den kontzeptu honen inguruko lehen ikerketa Felitti eta besteek (1988) egin zuten, jokabide-arazoak zituzten ikasleekiko ikuspuntua edota begirada aldatzea eraginez.

Guk, hain zuzen ere, eta lan honen izenburua horren lekuko da, kontzeptu honetan hartzen dugu arnas lan hau garatzeko. Esan behar da Estatu Batuetan nahiz Ingalaterran landu den begirada honetan jasotzen direla eskola-porrotan eragina duten faktore kognitibo, sozial, nahiz emozional gehienak. Kontzeptu honi dagokionean, hiru esperientzia gogor goiztiar bereizten dira, pertsonen etorkizunean eragiten duten trauma egoerak (Ruppert, 2016). Traumaz hitz egitean, Bessel Van der Kolk-ek (2019) emandako definizioa hartuko dugu:

Trauma pertsonaren biziraupenerako mekanismoak eta bizitzan zehar topatzen dituen egoerei aurre egiteko gaitasunak gainditzen dituen bizipena da. Pertsona horrentzako bizitza inoiz ez da berdina izango. Gainera, traumaren aurrean garuna aldatu egiten da, maila ezberdinetan, nerbio-sistema arriskuari aurre egin eta bizitzaren aldakortasunean jokatzeko gaitasuna izatea ahalbidetzen dion egoeran jarrita.

\subsection{Zer da haurtzaroko esperientzia gogor goiztiarrak kontzeptua?}

Esperientzia gogor goiztiarrak osasunean eta ongizatean ondorio traumatikoak eragin ditzaketen gertaerak dira (Sacks et al., 2014). Ikus 1. taulan kontzeptu honek barnean biltzen dituen egoera guztiak.

1. taula. Esperientzia gogor goiztiarrak

\begin{tabular}{|l|l|}
\hline \multirow{4}{*}{ Abusua } & Fisikoa \\
\cline { 2 - 2 } & Emozionala \\
\cline { 2 - 2 } & Sexuala \\
\hline \multirow{4}{*}{ Abandonua } & Fisikoa \\
\cline { 2 - 2 } Familian emandako \\
disfuntzioak & Emozionala \\
\hline \multirow{5}{*}{} & Arazo mentalak \\
\cline { 2 - 2 } & Kartzelaratzeak, atxiloketak... \\
\cline { 2 - 2 } & Genero-indarkeria \\
\cline { 2 - 2 } & Drogak, alkohola... \\
\cline { 2 - 2 } & Gurasoen banaketa \\
\hline
\end{tabular}

Iturria: Centers for Disease Control and Prevention et al. (2016). 


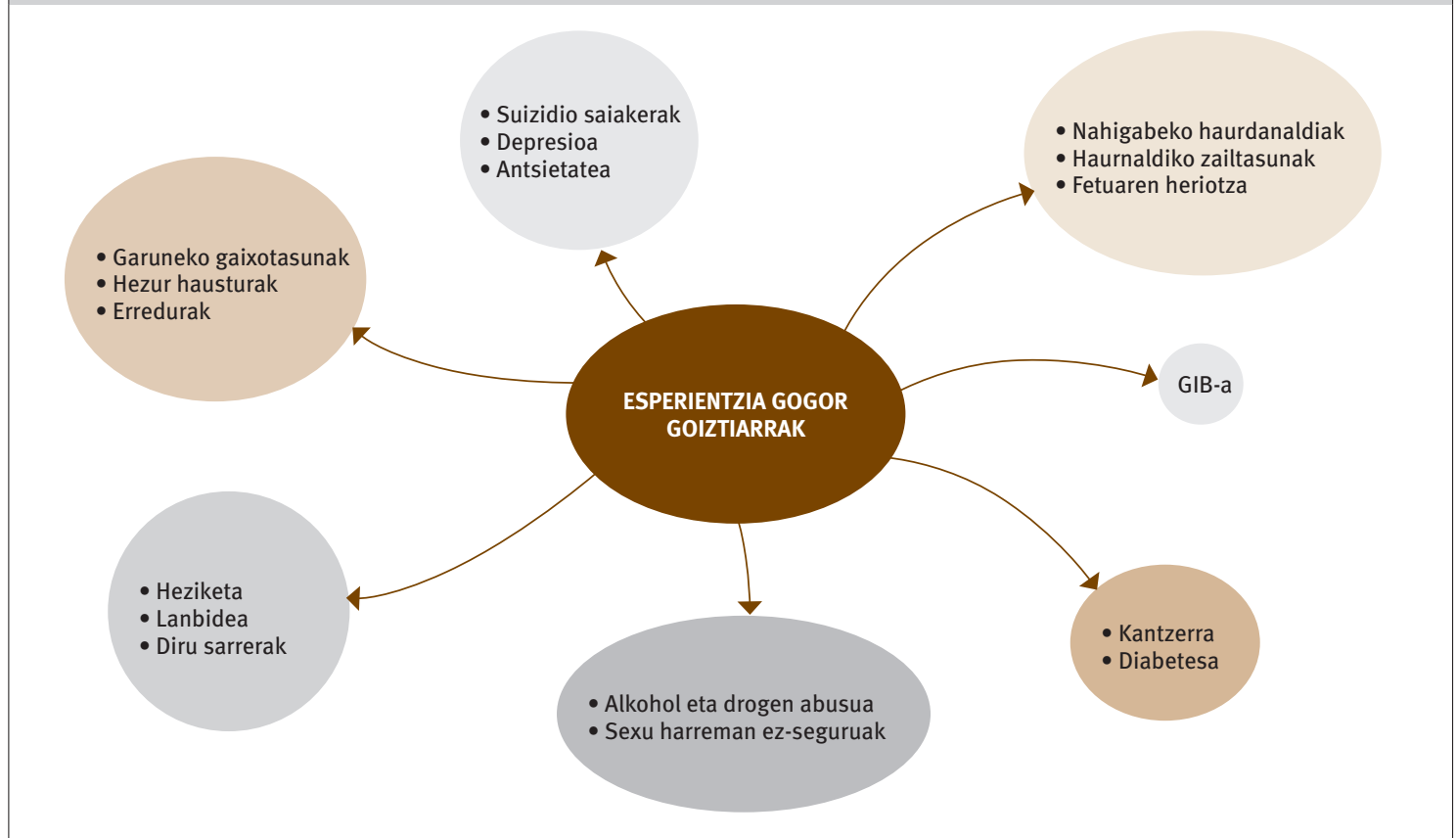

Iturria: Centers for Disease Control and Prevention et al. (2016).

Azken urteetan bizi esperientzia gogor goiztiarren inguruan egindako ikerketek jokabide eta osasunarekin loturiko ondorio negatiboak eragiten dituztela adierazten dute, hala nola: loditasuna, alkoholismoa eta depresioa (Sacks et al., 2014). Ondorio negatibo horien zerrenda luzatzen du CDCKaiser ikerketak (2016), 1. irudian ikus daitezkeenak.

Gaiaren inguruan egindako beste zenbait ikerketek adierazi dute ondorio negatiboak izateko arriskumaila eta jasandako esperientzia gogor goiztiarren kopurua zuzenean erlazionatuta daudela. Lehen aipatutako CDC-Kaiser ikerketak (2016) "dosierantzun” gisa definitzen du erlazio hori.

Esperientzia mota hauek traumak eragiten dizkiete haurrei, eta trauma hauek oharkabekoak izan ohi diren sintomak berekin dituzte, hala nola, frustrazioa, jokabide txarra, arreta mantentzeko zailtasunak, aginduak jarraitzeko eta taldean lan egiteko zailtasunak.

Errendimendu akademikoarekin duen erlazioari dagokionez, epe laburrean trauma-aurrekariak dituzten ikasleek errendimendu akademiko baxua izateko aukera gehiago dituzte. Izan ere, traumak ikasleen arreta mantentzeko gaitasunean, informazioaren prozesaketan, oroimenean eta ikaskuntzan eragiten du. Honek, gainera, haurraren garunean aldaketa neurobiologikoak eragiten ditu, estres egoera sortuz (Bruce, 2011).

Estresaren aurrean martxan jartzen diren sistemen etengabeko aktibazio egoerak garunaren garapena eta beste organo sistema batzuen funtzionamendua oztopatu dezake. Izan ere, estres egoera hori bizitzen ari den haurra ez da arrazoizko eran pentsatzeko gai eta psikologikoki ezinezkoa egiten zaio eduki berriak barneratzea (Goddard, 2016). Horretaz gain, helduaroan estresarekin erlazioa duten gaixotasunen agerpena eta narriadura kognitiboa emateko arriskua handitzen du (American Academy of Pediatrics, 2014).

Gaur egun, neuroirudiaren inguruan egin diren ikerketek adierazi dute haurtzaroan tratu txarrak jasan izanak garunaren egituratzean eragin zuzena duela, hipokanpoan, amigdalan, zerebeloan eta kortex-zerebralean hain zuzen ere (Mesa eta Moya in Barca, 2015).

Laburbilduz: bizipen traumatikoak izateak garunaren garapena oztopatu eta epe labur zein luzeko ondorio negatiboak eragin ditzake ongizate sozial, emozional eta psikologikoan. Ondorioz, zailtasun kognitiboak, garapen atzerapena, jokabide eta emozioen erregulaziorako arazoak, errendimendu akademikoaren jaitsiera, delinkuentzia, zenbait substantzien kontsumoa eta gaixotasun mentalen agerpena ematen dira (Delaney-Black et al. in Maynard et al., 2017).

Aipatutako ondorio horiek guztiak modu progresiboan agertu ohi dira, denborak aurrera egin ahala euren larritasuna handituz. Oso ongi adierazten du prozesua 2. irudiak, hasierako garapen neurologikoaren alterazioak heriotza goiztiarrean amaitu daitekeen prozesua abiarazten duelarik.

Hala eta guztiz ere, pertsona guztiek ez dute erreakzio bera izaten, jatorri ezberdineko ezaugarriek (gertaeraren baldintza zehatzak, ematen den giro soziokulturala, garapen-fasea, etab.) baldintzatzen dute erreakzio hori eta (Labrador eta Alonso in Soler, 2008). 


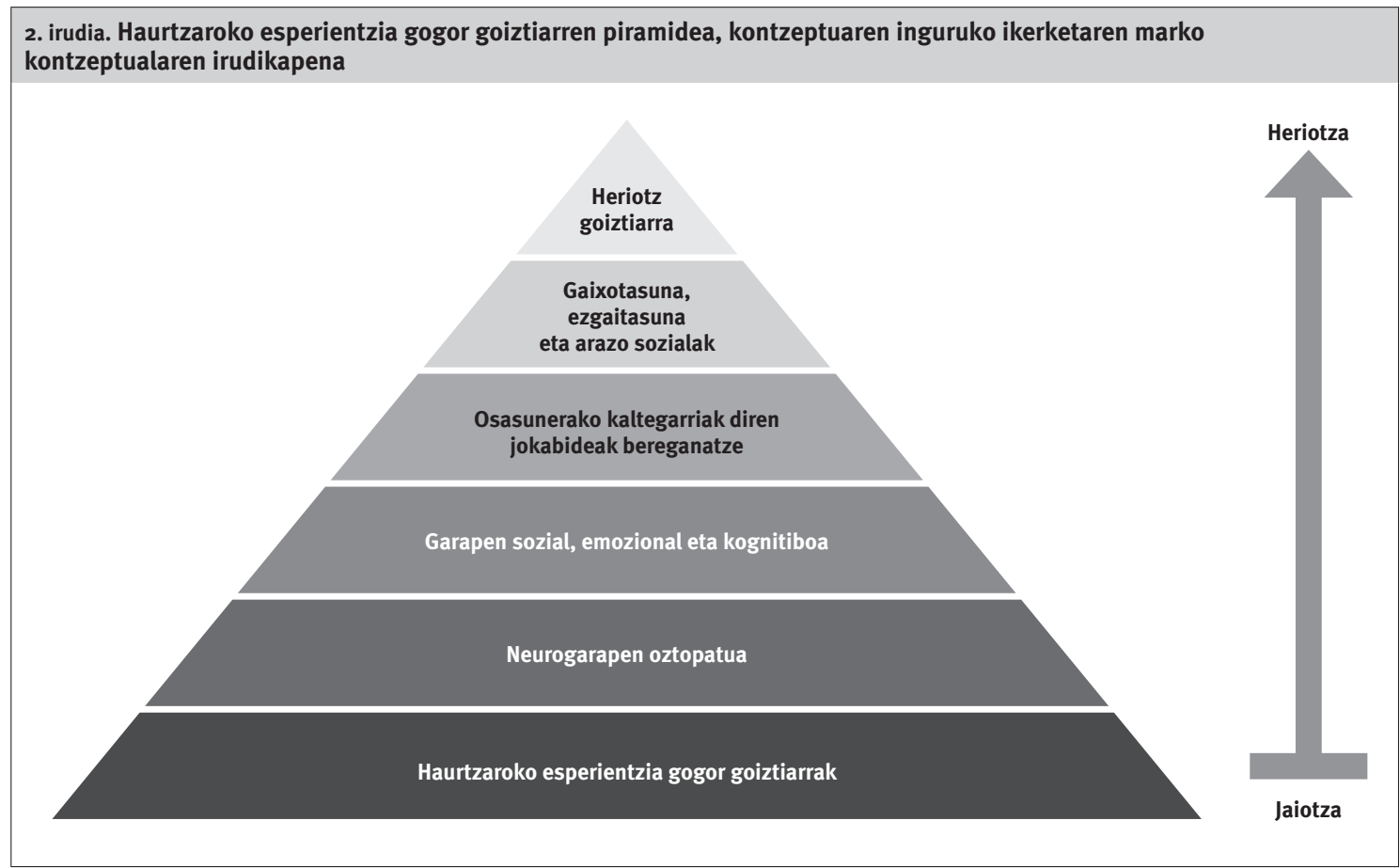

Iturria: Centers for Disease Control and Prevention et al. (2016).

Beraz, lan honetan, Felitti et besteek (1988) zerrendatutako haurtzaroko esperientzia gogor goiztiar ezberdinak aztertuko dira, bakoitzaren ezaugarriak eta ikasleengan eragiten dituzten ondorioak azalduz.

\subsection{Kontzeptuaren inguruko kasu-azterketa}

Lanean zehar landuko den atxikimenduaren gaiarekin erlazio zuzena duen kasua abandonua denez, hau landuko da lehenik.

\subsubsection{Abandonuo}

Haurtzaroaren aurkako tratu txarrak lau mota ezberdinetan sailka daitezke: tratu txar fisikoa, sexuabusua, abandonua eta tratu txar orokorra (Cichetti eta Carlson in Rosa-Alcázar et al., 2010). Espainiaren kasuan, eta 2012ko Boletín de Datos Estadísticos de Medidas de Protección a la Infancia-ren arabera, abandonu fisikoa da haurtzaroaren aurkako tratu txarren artean salaketa gehien jasotzen dituena, tratu txar emozional eta abusu sexualaren aurretik (Jiménez Grande, 2016).

Hala eta guztiz ere, haurtzaroaren aurkako tratu txarrak definitzerakoan kontuan izan behar da adingabekoaren ongizatearen arduraduna nor den, testuinguruak eragin handia baitu horretan. Izan ere, tratu txarrez hitz egiterakoan euren seme-alaben oinarrizko beharrak erantzuteko gai ez diren gurasoak hartzen baditugu kontuan, pobrezian bizi diren familia guztietako seme-alabak tratu txarrak jasaten dituzten adingabekoak direla esan beharko genuke.
Horregatik, eta definizio zabal horrek eragin dezakeen gaizki ulertua saihesteko asmoz, kasu honetan guraso edota tutoreen omisioaren eraginez sortutako abandonua da azalduko dena, euren erantzukizun edo betebeharrak ez betetzearen ondorioz emandakoa (Manso, 2001).

\subsubsection{Abandonu fisikoa}

Abandonu fisikoa, emozional eta fisikoaren artean ohikoena (Wolfe eta Pierre in Osuna et al., 2000) eta gutxien ikertu dena (Crouch eta Milner in Osuna et al., 2000). Egoera hau pairatzen duen haurrak agertu ditzakeen adierazleak 2. taulan azaltzen dira.

2. taula. Abandonu fisikoaren adierazleak

\begin{tabular}{|l|l|}
\hline Elikadura & $\begin{array}{l}\text { Ez zaio elikadura egokia eskaintzen eta } \\
\text { gosez dago. }\end{array}$ \\
\hline Arropa & $\begin{array}{l}\text { Ez du eguraldiaren araberako arropa egokia } \\
\text { erabiltzen. }\end{array}$ \\
\hline Higienea & Uneoro zikin dago, gorputz-higiene eskasa. \\
\hline Zainketa medikoak & $\begin{array}{l}\text { Erantzun gabeko arazo fisikoak edota ohiko } \\
\text { zainketa medikuen gabezia. }\end{array}$ \\
\hline Gainbegiratzea & $\begin{array}{l}\text { Denbora asko ematen du heldu baten } \\
\text { gainbegiratze eta zaintza gabe. }\end{array}$ \\
\hline $\begin{array}{l}\text { Segurtasun- } \\
\text { baldintzak }\end{array}$ & $\begin{array}{l}\text { Adingabekoaren osasun eta } \\
\text { segurtasunarentzako arriskutsuak diren } \\
\text { etxeko higiene eta segurtasun baldintzak. }\end{array}$ \\
\hline Hezkuntza-arloa & $\begin{array}{l}\text { Eskolara ez joate errepikatu eta justifikatu } \\
\text { gabea. }\end{array}$ \\
\hline $\begin{array}{l}\text { Estimulazio } \\
\text { kognitiboa }\end{array}$ & $\begin{array}{l}\text { Bere adin, behar eta eskakizunetara } \\
\text { egokitutako gutxieneko estimulazioaren } \\
\text { gabezia. }\end{array}$ \\
\hline
\end{tabular}

Iturria: Arruabarrena eta De Paúl (1999). 
Tratu txar mota honek ondorio askotarikoak ditu: kalte fisikoak, arazoak garapen fisiko zein kognitiboan, sintoma depresiboak, trauma osteko estresa, antsietatea, egokitzapen eta elkarrekintza sozialerako arazoak, jokabide asaldurak, autoestimuaren jaitsiera... (Cichetti eta Carlson in Rosa-Alcázar et al., 2010).

Ondorio horiez gain, jokabide eta alderdi emozionalean honako erreakzio hauek eragin ditzake ere: nekea, apatia edo logura, janaria lapurtu edo eskatzea, eskolara ez joatea edo berandu ailegatzea edo leku publikoetan edo eskolan bakarrik denbora asko igarotzea. Epe luzera, droga edo alkoholaren gehiegizko kontsumoa, eskola-uztea, etxetik ihes egiteak, bataz bestekoa baino hitz egiteko gaitasun eta gaitasun kognitibo urriagoak, gehiegizko agresibitatea edo muturreko pasibotasuna, muturreko adierazpen afektiboak, pesimismoa, konfiantza-gabezia, depresioa edo epe luzeko erlazioak mantentzeko ezintasuna eragin ditzake (González, 2007).

\subsubsection{Abandonu emozionala}

Abandonu emozionala, fisikoaren kasuan bezala, adingabekoaren arduradunek haren babesa ez bermatzearen edo beraien betebeharra behar bezala ez burutzearen ondorioz ematen da. Hori dela eta, tratu txar emozionalarekin batera "haurrarengan eragiten dituen kalteak identifikatzerakoan zailtasun gehien dituen haurtzaroarekiko tratu txar mota da" (Manso, 2004: 216).

Arruabarrena eta De Paúl-en (in Manso, 2004) arabera abandonu emozionala adingabekoak bere elkarbizitzako unitatea osatzen duten kideekiko interakzio gabeziaren ondorioa da. Honen adierazle dira guraso eta seme-alaben arteko interakzio gabezia edo urritasuna, haurraren estimulazio urria eta seme-alabek egindako gertutasun, kontaktu eta interakzio seinaleekiko gurasoen erantzunen gabezia. Honek guztiak haurraren garapen ebolutiboa oztopa dezake. Honako hauek dira abandonu emozionala eragiten duten jokabideak: 1) ez ikusiarena egitea; 2) laguntza psikologikoari errefusatzea; 3) laguntza psikologikoaren atzerapena. Aipatutako jokabide horietan guztietan, abandonu emozionala ematen dela esango da ondorengo bi baldintzak aldi berean agertzen badira: jokabidearen presentzia erabat nabarmena da eta kalte emozionala eragiten duten jokabideak larritasun handieneko muturrean kokatzen dira (jokabideak etengabekoak eta intentsitate handikoak dira, haurraren egoera emozionalean kalte larriak eragin dituzte edo eragin ditzakete, bere garapena arrisku larrian dago eta berehalako tratamendu espezializatua behar du) (Arruabarrena eta De Paúl, 1999).

Azkenik, nahiz eta abandonu emozionalaren eragin edo ondorio negatiboak identifikatzeak zailtasuna duela esan, honako hauek dira Gabarino eta Gaudin-en arabera (in Manso, 2003) tratu txar mota honek haurren ikaskuntza-prozesuan eragiten dituen kalte nagusiak: lengoaia arruntean urritasun nabarmenak, kontzeptuak orokortu eta abstraditzeko ezintasuna eta beste pertsonekin harremanak izateko eta testuinguruak eragindako presio minimoaren aurrean bulkadei eusteko zailtasuna.

\subsubsection{Abusua}

"Adingabeen abusua" kontzeptua definitzea haren errealitate konplexu eta heterogeneoak eragindako zailtasunez beteta dago. Heterogeneotasun honek abusuaren nozioa, hura sailkatzeko baliatutako irizpide ezberdinak, fenomeno honekin erlazionaturiko ikuspegi profesionalen aniztasuna eta bere kausa eta ondorioak barnean biltzen ditu. Hala eta guztiz ere, zailtasun horiek guztiak egon arren, badago definizioaren inguruko adostasun bat, zeinaren arabera: adingabekoen segurtasuna mehatxatu edo oztopatzen edo beraien behar fisiko eta psikologikoak eskuratzea eragozten dien ustekabekoa ez den edozein ekintza edo omisioa (Palacios et al., 1995).

Abusuaren barnean, hiru mota bereizi ohi dira: fisikoa, emozionala edo psikologikoa eta sexuala (Robaina, 2001). Guk sexuala bakarrik aipatuko dugu. Adingabekoen aurkako abusu sexuala biktimaren garapen egokia oztopatzen duen osasun publikoko arazo larria da, haren egoera fisiko eta psikologikoan modu negatiboan eragiten duena (Pereda, 2009). Gaur egun, nazioarte-mailan eragin eta prebalentzia handia duen arazoa da. Osasunaren Mundu Erakundearen arabera, munduan zehar gutxienez 150 milioi neskek eta 73 milioi mutilek abusu sexual motaren bat jasan dute 18 urte bete aurretik (Mebarak et al., 2010).

Adingabekoen aurkako abusu sexuala definitzerakoan autore gehienek Finkelhor eta Hotaling-ek proposatu eta López-ek berretsitako hertsadura eta asimetria irizpideak jarraitzen dituzte (Pereda, 2009). Hertsadurak adingabeko batekin indar fisiko, mehatxu, presio, autoritate edo engainuaren bitartez izandako kontaktu sexualari egiten dio erreferentzia.

Bestalde, adinaren asimetriak adingabekoaren benetako erabakitze askatasuna eragotzi eta harreman sexual partekatua izatea galarazten du. Izan ere, parte-hartzaileek bizipen, heldutasun biologiko eta itxaropen oso ezberdinak dituzte. Hortaz, hertsadura, adin-asimetria edo biak batera ematen diren adingabeko eta beste pertsona baten arteko harreman sexualak abusu gisa kontsideratu beharko dira (Cantón, Cortés eta López in Pereda, 2009).

Abusu sexual gisa ulertzen diren jokabideak, ekintza isolatuak izaten ez direnak, kontaktu fisikoa (genital, anala edota ahokoa) edo adingabekoa erasotzailea sexualki estimulatzeko objektu gisa erabiltzea (exhibizionismoa edo pelikula pornografikoen proiekzioa) izan daitezke. 
Kasu gehienetan, abusu sexuala familiako kideren batek (guraso, anai-arreba nagusiek...) -intzestua emanez- edo biktimarekin erlazioa duen pertsonaren batek (irakasle, entrenatzaile, monitore...) burutzen du (Echeburúa eta Guerricaechevarría in Echeburúa eta Corral, 2006).

Salaketak egiterako orduan adingabeek muga ugari eta ez dutenez normalean adierazle fisiko zehatz eta eztabaidaezinik, garrantzitsua da jakitea 3. taulan agertzen diren adierazle hauek direla ohikoenak (Echeburúa eta Corral, 2006).

3. taula. Abusu sexuala jasan duten adingabekoen adierazleak

\begin{tabular}{|c|c|c|}
\hline Adierazle fisikoak & $\begin{array}{l}\text { Jokabide- } \\
\text { adierazleak }\end{array}$ & $\begin{array}{l}\text { Alderdi sexualeko } \\
\text { adierazleak }\end{array}$ \\
\hline $\begin{array}{l}\text { - Mina, zauriak } \\
\text { edo kolpeak } \\
\text { genitaletan eta } \\
\text { uzkian. } \\
\text { - Bulba handitua } \\
\text { eta gorritua. } \\
\text { - Barneko arropa } \\
\text { hautsita eta } \\
\text { odolez zikindua. } \\
\text { - Ibili eta esertzeko } \\
\text { zailtasunak }\end{array}$ & $\begin{array}{l}\text { - Jateko gogo eza. } \\
\text { - Helduren batekin } \\
\text { bakarrik egoteari } \\
\text { beldurra. } \\
\text { - Bat bateko } \\
\text { negarraldiak. } \\
\text { - Biluztu eta } \\
\text { bainatzeari } \\
\text { errefusa. } \\
\text { - Guraso batekiko } \\
\text { bat-bateko } \\
\text { aldentzea. }\end{array}$ & $\begin{array}{l}\text { - Laztan, muxu eta } \\
\text { kontaktu fisikoa } \\
\text { ukatzea. } \\
\text { - Jokabide } \\
\text { seduktoreak, } \\
\text { nesketan batez } \\
\text { ere. } \\
\text { - Bere adinerako } \\
\text { jokabide sexual } \\
\text { ezohikoak. } \\
\text { - Orientazio } \\
\text { sexualaren } \\
\text { inguruko } \\
\text { nahasmena. }\end{array}$ \\
\hline
\end{tabular}

Iturria: Echeburúa eta Corral (2006).

Honekin amaitzeko, abusu sexualek eragindako ondorio negatiboez hitz egingo da. Ondorioei dagokienez, epe labur zein luzekoak ematen dira (López et al., 1995). Epe laburrekoen inguruan dagoen bibliografia aztertu ondoren, Pereda-k (2009: 136-137) bost multzo ezberdinetan sailkatzen ditu: arazo emozionalak (traumak, antsietatea, depresioa, autoestimu baxua, errudunsentimendua eta jokabide suizida), alderdi kognitibo eta errendimendu akademikoarekin erlazionatuak (hiperaktibitatea eragin dezaken arreta mantentzeko zailtasuna), arazo sozialak (konfiantza hartzeko zailtasuna dela eta), arazo funtzionalak (loa, esfinterren kontrola eta elikadurarekin erlazionatutako arazoak) eta jokabide-arazoak (jokabide sexualizatua, adostasun konpultsiboa eta jokabide disruptiboa eta agresiboa).

Epe luzekoen kasuan, aldiz, Pereda-k (2010: 192-195) zazpi multzotan bereizten ditu: arazo emozionalak (depresioa, bipolaritatea, trauma ondorengo estresa, pertsonalitatearen muturreko desoreka, jokabide autodestruktiboak, ideia eta ekintza suizidak eta autoestimu baxua), arazoak erlazioetan (isolamendu eta antsietate soziala, lagun eta interakzio sozial gutxi, bikotearekin arazoak, semealabak hezteko modu permisiboa eta zigor fisikoa erabiltzeko tendentzia), jokabide eta egokitzapen sozialerako arazoak (jokabide antisozialak, jokabideasaldurak, etxetik ihes egitea eta delituak egitea eta ondorioz atxilotua izatea), arazo funtzionalak (arrazoi medikorik gabeko minak, bulimia, identitate asaldurak), arazo sexualak (sexualitate disfuntzionala eta harreman sexual arriskutsuak), berriro ere biktima izateko aukera eta ondorengo belaunaldietara transmititzeko arriskua.

Azkenik, aipagarria da abusua (fisikoa, emozionala edo sexuala) muturrekoa denean, euren intentsitate eta maiztasunagatik, biktimaren pertsonalitatearen garapen globala kaltetu dezakeela. Izan ere, bertatik ihes egitea ezinezkoa den giroan bilakatzen da, berarentzako erreferentziazko mundua izanez (Soler, 2008).

\subsubsection{Familian emandako disfuntzioak}

Ikaslearen testuinguruari buruz hitz egiterakoan, familia da bururatzen zaigun lehen esparrua, gurasoak baitira euren seme-alaben heziketaren arduradun nagusiak, euren parte-hartzea ezinbestekoa izanik (Estado de Sonora, Plan Estatal de Educación 2001-2007 in Valdés et al., 2011). Gainera, ikasleen arrakasta akademikoa eskolak zein familiak luzatu edota emandako baliabideekin erlazionaturik dagoenez, ezinbestekoa da familia bakoitzaren errealitatea ezagutzea, honek, ikasleen arteko aldea ulertzen lagundu diezaguke eta (Chiu, 2010).

Beraz, ikasle bakoitzaren familiaren egoera ezagutzea ezinbestekoa da, haren ahulgune eta indar-guneak identifikatuta izatea, horren bitartez testuinguruak eragindako gabeziak indartzeko eskuartzeak diseinatu ahal izango direlako. Alde batetik, familiaren egoera sozioekonomikoa eta, bestetik, familia mota dira familiaren background-a osatzen duten alderdiak (Robledo-Ramon, 2016).

Lan honetan, familiaren barnean ematen diren disfuntzioetan eta honek ikaslearen ongizate emozionalean, eta ondorioz, errendimendu akademikoan, duen eraginean zentratuko gara.

\subsubsection{Arazo mentalak}

Argitalpen eta ikerketa ezberdinek adierazi dute arazo mental larriak dituzten gurasoak euren semealaben garapenerako arrisku faktorea direla (Del Hoyo eta Rodríguez, 2004). Izan ere, haurtzaroko lehen urteetan gurasoekiko erlazio eta afektua haurraren garapen ebolutiboa egokia izan dadin oso garrantzitsuak direnez, afektibitate desegokia adierazten duen sintoma psikotikoak dituen guraso bat izateak ondorio larriak izan ditzake haurrarengan (Stern in Del Hoyo eta Rodríguez, 2004).

Ondorio horiei dagokienez, zenbait ikerketek jokabide, emozio eta garapen ebolutiboko arazoak aipatzen dituzte (Klimes-Dougan et al. eta Lazarus eta Folkman in Maybery et al., 2005). Beste zenbaitek, aldiz, haurrak garatzen duen atxikimendu motaren inguruan jardun dute, egoera horretan bizi diren haurrek beraien gurasoekiko atxikimendu 
ekiditezkoa, larritasun handiko atxikimendu anbibalentea edo desantolatu-desorientatua izaten dutela esanez (Rutter, 1986).

Lanean zehar atxikimenduaz eta honen garrantzi eta eraginaz gehiago hitz egingo denez, atal honetan ez da honen inguruan gehiago sakonduko.

\subsubsection{Kartzelaratzeak edo atxilotzeak}

Guraso baten kartzelaratze, edota atxiloketa hutsak, ondorio latzak eragiten dizkio haren semealabari, hala nola, tristura, haserrea, egonezina eta galera-sentimendua (Robertson, 2007). Horretaz gain, egoera hori bizi duten haurrek antsietatea, neurosia, pertsonalitate aldaketak, jokabide agresiboak eta bere garapen emozional, kognitibo eta psikomotorrean eragiten duen epe luzeko estresa pairatzen dituzte (Larman eta Aungles, 1991).

Ondorio hauek sailkatzerakoan, King-ek (2002: 11-12) hiru multzo bereizten ditu: eragin ekonomikoak (preso gehienak testuinguru pobreetatik datozenez eragin zuzena dute familiaren egoera ekonomikoan), jokabide eta ongizate emozionalekoak (jokabide agresiboak, obedientzia-maila baxuak eta errendimendu akademikoaren eskastea) eta familiarekiko estimaziokoak (presio soziala bereziki, ingurukoek gertatu denaren berri ez nahi izatea eraginez) .

Gai honen inguruan modu sakonean hitz egiten du Robertson-ek (2007) El impacto que el encarcelamiento de un(a) progenitor(a) tiene sobre sus hijos liburuan, non kartzelaratze prozesuan zehar ematen diren etapa bakoitzak semealabengan duen eragina azaltzen duen. Etapa horiek kartzelaratzearen aurretikoa, kartzelaratzearen zeharrekoa eta kartzelaratzearen ondorengoa dira, bakoitzaren ezaugarri nagusiak azaltzen dituelarik.

\subsubsection{Genero-indarkeria}

Espainian, 1/2004 Genero Indarkeriaren kontrako neurriak arautzeko Lege Organikoak honela definitzen du genero-indarkeria: "Genero-indarkeria emakumeei emakume izateagatik egiten zaien indarkeria da, erasotzaileen iritziz ez dutelako askatasun, errespetu eta erabakitzeko gaitasunen inguruko inongo eskubiderik merezi". Indarkeriaekintzei dagokienez, Lege horren 1.3 artikuluak eraso fisiko eta psikologikoak aipatzen ditu, askatasun sexuala, mehatxuak, hertsapenak eta askatasungabetzea barnebiltzen dituztenak.

Hala eta guztiz ere, kontuan izan behar da indarkeria mota hau jasaten duten emakumeen seme-alabak ere egoera horren biktima direla (Sepúlveda, 2006), indarkeria hori ikusteak adingabeko horien ongizate psikologikoan ondorio larriak eragin baititzake (Hernández eta Gras, 2005). Izan ere, gaiaren inguruan egindako zenbait ikerketek adierazi duten bezala, familiaren barneko genero-indarkeria bizi izan duten seme-alabek, esperientzia hori izan ez dutenekin alderatuz, jokabide agresibo eta antisozialagoak eta beldur handiagoa izaten dituzte (Hughes eta Hughes, eta Parkinson eta Vargo in Hernández eta Gras, 2005).

Horretaz gain, horrelako egoerak bizi dituzten etxeetan, umeek gaitasun sozial eta errendimendu akademiko baxuagoa (Adamson eta Thompson, eta Rossman in Hernández eta Gras, 2005) eta antsietate, depresio eta sintoma traumatiko handiagoa izaten dute (Maker et al. eta Stenberg et al. in Hernández eta Gras, 2005). Gainera, ama bere bikotearen beldur bada, seme-alabaren beharrei erantzuteko gaitasuna galdu dezake, haien elikadura eta loaren errutinak eta atxikimenduaren oinarrizko beharrak aldatuz (Wolfe eta Korsch in Ulloa, 1996).

\subsubsection{Alkohol edo drogekin arazoak}

Jakina da familia askoren egunerokotasunean, alkoholarekin arazoak dituzten gurasoengatik aztoratuak izaten direla edo modu ezkorreko eragina izaten dutela. Familia horietako seme-alabak, tamalez, abusua, arduragabekeria edo abandonua, etxeko biolentzia edo familia barneko beste motatako disfuntzioak pairatzeko arriskuan daude (Windle et al. eta US Department of Health and Human Services [HHS] in Dube et al., 2001).

Hori dela eta, etorkizunean haiek ere alkoholarekin arazoak izateko aukera handia izateaz gain, alkoholismoarekin erlazionatutako arazo sozial, psikologiko, fisiko eta ekonomikoak pairatzeko arriskuan daude: arazo ekonomikoak pertsona alkoholikoak ezin duelako lana egin edo dirusarreren kopuru handi bat alkoholean xahutzen duelako; isolamendu soziala arazoa etxekoei ezkutatzen ahalegintzeagatik; eta ondorio fisiko edo psikologikoak gurasoek alkoholaren eraginen menpe egonda jasotako tratu txarrengatik, besteak beste (Department of Health and Human Services eta Jackson in Schoenborn, 1991).

Hortaz, alkoholarekin arazoak dituzten gurasoen seme-alabek duten arrisku handiena gainerako haurtzaroko esperientzia gogor goiztiarrak eta horiek eragindako ondorio negatiboak pairatzea da (Dube et al., 2001). Zehatzagoa izanik, Poon eta besteek (2000) alkoholarekin arazoak dituzten gurasoen seme alaben errendimendu akademikoaren inguruan egindako ikerketak adierazi zuen haur horiek, arazo horiek ez dituzten gurasoen seme-alabekin alderatuz, arreta, abstrakzio eta errendimendu akademiko baxuagoa dutela.

Bestalde, ikerketek erakutsi dute alkohol edo drogekin arazoak dituzten gurasoen seme-alabek arazo emozional, jokabidezko, akademiko, delituzko eta sozialak izateko arrisku handia dutela (Kelly; Fals-Stewart eta Kumpfer; eta Fowler in Kumpfer eta Jubani, 2013). Gainera, ume hauek haurdunaldian 
zehar alkohol edo drogen eragina pairatu izana ere etorkizunean arazoak izateko arrisku-faktore garrantzitsua da (Kumpfer eta Fowler in Kumpfer eta Jubani, 2013).

\subsubsection{Gurasoen banaketa}

Gaur egun, geroz eta gehiago dira gurasoen banaketa-prozesuren bat edo familiaren berregituraketaren bat bizitzen ari diren ikasleak, ohiko familiaren eredutik kanpo gelditzen direnak. Aldaketa horiek haien garapen pertsonalean, sozializazio-eremu berriekiko egokitzapenean eta familia-kontzeptuaz eraikitzen duten irudi edota ikuspuntuan eragiten dute (Iribarren, 2010). Bestalde, prozesu hauetan ematen diren aldaketak (etxea, ikastetxea edota lagunak esaterako) esperientzia estresagarri gisa bizi ditzake umeak, eta eskolara joateari beldurra izatea edota arazo psikologikoren bat garatzea eragin ahal izanda (Rodríguez in Orgilés et al., 2008).

Banatutako gurasoak dituzten ikasleek errendimendua jaisten dute banaketa eman eta hurrengo urtean zehar, aldi berean portaeraarazoak garatzen hastearekin batera (Cantón et al., 2002). Horretaz gain, gurasoen artean sortzen den giro negatiboak portaera-arazo horien garapena sustatzeaz gain, seme-alabak depresiora bidera ditzake (Lengua et al. in Duarte et al., 2002). Beraz, argi ikusten da, egoera honek seme-alabengan maila emozionalean, sozialean zein eskolako esparruan modu negatiboan eragiten duela (Orgiles eta Piñero in Bolívar, 2017).

Hainbat ikerketek aztertu dute gurasoen banaketak seme-alaben eskola-bizitzan duen eragina, egoera honetan dauden ikasleek zailtasun akademiko gehiago, test estandarizatuetan maila baxuagoa eta lorpen-motibazio zein hezkuntza-helburu baxuagoak dituztela adieraziz. Hori dela eta, ikasle hauek beraien ikasketak Derrigorrezko Bigarren Hezkuntzan alde batera uzteko arriskua dago (Cantón et al. in Bolívar, 2017).

Aldiz, maila emozional eta sozialean duen eraginari buruz, Bolívar-rek (2017) "Los niños ante la ruptura parental" lanean Sadowski eta Mcintoshek euren ikerketatik ateratako ondorioa biltzen du, zeinak gurasoen banaketaren ondorioz guraso bakoitzarekin txandaka bizi diren seme-alabak dudatsuak eta ahulak sentitzen direla baitio. Gainera, gurasoen arteko gatazkek lotura zuzena dute seme-alaben autoestimu baxuan (Coopersmith in Frías et al., 1992).

\subsection{Atxikimendu-arazoak}

Gizakia bere buruaz zainduko duen heldu batekiko menpekoa izaten jaiotzen da. Gainerako espezieekin alderatuz gero, pertsona independente eta arduratsu gisa garatzeko konpainia, zainketa, gomendio eta babesaren beharra dugu urte askotan zehar. Azken batean, haur batek zaintzaile baten, edo gehiagoren, etengabeko presentzia behar du norbait izatera heltzeko (Barudy eta Dantagnan, 2010).

Hori dela eta, lehen urteetan haurraren zaintza eta ongizateaz arduratzen den zaintzailearen eta haurraren arteko atxikimendu seguruko erlazioa ezinbestekoa da "haurrak bere izatea osatzen duten alderdi guztien garapen egokia izan dezan: emozionala, kognitiboa eta soziala" (Bowlby in Sonkin, 2005: 68).

Atxikimenduarekin erlazionatutako jokabideen sistema haurraren eta bere atxikimendu-figuraren arteko gertutasuna eta kontaktua mantentzea ahalbidetzen duten jokabideen multzoa da (irribarreak, negarrak, kontaktu fisikoak, etab.). Hauek atxikimendu-figurarekiko distantzia handitzean edo arrisku-seinaleak hautematean gertutasuna berreskuratzeko jartzen dira martxan (Bowlby in Oliva, 2004).

Hortaz, atxikimendua ez da estimulu edo seinale zehatz baten aurrean agertzen den jokabide instintiboa, "testuinguru eta banakoaren aldagaien eta hauen intentsitatearen arabera agertzen diren jokabide ezberdinen segida baizik" (Oliva, 2004: 65).

Schaffer eta Emerson-ek (1964) haurrek euren bizitzako lehen bi urteetan beraien familiekiko duten erlazioaren inguruan egindako ikerketak adierazi zuen haurrek beraien gurasoekiko sortzen zuten erlazio mota, hein handi batean, azken hauek haurren beharrei erantzuteko duten sentsibilitate eta gaitasunaren araberakoa dela. Hori dela eta, erlazio mota ezberdinak izan ditzaketenaren ideiari helduta, Mary Ainsworth-ek (in Jauregizar, 2019) hiru atxikimendu mota ezberdindu zituen: segurua, ekiditezkoa eta larritasun handiko atxikimendu anbibalentea. Bessel Van der Kolk-ek aldiz (2014) laugarren mota bat gehitu zuen: desantolatu-desorientatua.

Atxikimendua segurua izateak, hau da, gertutasun eta segurtasunean oinarrituriko erlazioak, haurrei segurtasun handia, autoestimu altua, garapen integrala (kognitiboa, emozionala, soziala, motorra eta sentsoriala) eta esplorazio eta autonomiarako askatasuna izatea ahalbidetzen die. Hori dela eta, haurrak estrategia egokituak erabiltzen ditu bere behar eta erlazio afektibo eta sozialen inguruko erantzunak jasotzeko. Gainera, guzti honi esker, estresari aurre egiteko eta bere emozioak erregulatzeko gai izango da.

Hortaz, atxikimendu segurua duen haurrak bere buruarekiko balorazio positiboa eta inguruan dituen pertsonak konfiantzazkoa direlakoaren pentsamendua izango du, bere beharrak asetzeko prest egongo direla jakinda (Bartholomew eta Horowitz, 1991). Torquati eta Vaszonyi-k (in Reyes Pérez eta Reidi, 2015) diote atxikimendu segurua duten haurrak egoera estresagarriei aurre egiteko 
gaitasunagatik nabarmentzen direla, estrategia egokiak erabiliz eta egoerak modu egokien erregulatuz.

Honen inguruan ikertu zuten Ainsworthek eta haren lankideek 70. hamarkadan, haurra, eremu ezezagun batean, bere amarengandik denbora labur batez aldendu eta itzultzean izandako jokamoldea aztertuta. Egoera hori "egoera arrotz" gisa ezagutzen da. Ikerketa honek erakutsi zuen atxikimendu segurua zuen haurrak ama agurtzen zuela hura itzultzean eta kontaktu fisiko eta gertutasun afektiboarekin lasaitzen zela. Gainera, banandu aurreko egoera berrezartzeko gai izaten zen ere (Van der Kolk, 2014).

Ekiditezko atxikimendua duen haurrak, aldiz, kaltegarria izan daitekeen gertutasunetik alde egiten du. Ezaugarrien artean, honako hauek dira nagusitzen direnak: elkarrekintza afektibo gutxi, banatzeagatik estutasun gutxi, ezezagunekin atxikimendu-figurarekin duen harreman bera $\mathrm{du}$, bere burua babesteko etengabeko jokabidea adierazten du, afektuaren beharra ukatzen du mindua edo arbuiatua izatea saihesteko, amaren babes eta zainketa errefusatzen du eta jokabide agresiboa izan ohi du.

Beraz, intimitatea saihesten du, bere buruarekiko ikuspegi positiboa du, ez da besteez fidatzen eta bere burua babesten du distantzia jarriz eta bere independentziarako beharra neurriz kanpo balioztatuz (Bartholomew, 1990).

Ainsworthek eta besteek 1978 urtetik aurrerantzean eramandako ikerketak honako emaitzak jaso zituen ekiditezko atxikimendu mota zuen haurra "egoera arrotzean" kokatzerakoan: ez zuen negarrik egiten amarengandik banatzean, haren itzuleran ez zion jaramonik egiten, ez zuen harremanik bilatzen ezta haserre egotearen keinurik egiten ere, eta jostailuetan eta testuinguruan jartzen zuen arreta (in Casullo eta Fernández Liporace, 2005).

Ikerketek adierazi dute ekiditezko atxikimendua duten haurrek, atxikimendu segurua dutenekin alderatuz, barneratze- eta kanporatze-maila altuagoak izaten dituztela (Muris et al., 2003). Barruratze-sindromeak herabetasun, antsietate eta depresio-arazoei eta gutxiagotasun, lotsa, autokontzientzia eta hipersentsibilitate sentimenduei egiten die erreferentzia. Kanporatze sindromeak, aldiz, jokabide disruptibo, agresibo eta antisozialak eta hiperaktibitate, arreta mantentzeko eta autokontrolerako arazoak barnebiltzen ditu (Bornstein et al., 2013).

Bestalde, larritasun handiko atxikimendu anbibalentea duen haurra gertutasun afektiboarekiko hurbiltze- eta erresistentzia-fasean sartzen da. Egoera horretan, ez dauka atxikimendu-figura segurtasun oinarri gisa erabiltzeko gaitasunik, banatzeagatik estres anbibalentea adierazten du, atxikimendu-figura erabilgarri egoteak kezkatzen du, kontaktua bilatu arren azken momentuan ukatu egiten du, ez da lasaitzen ezezagun batekin, jokabide agresiboa adierazten du eta esplorazioarekiko beldur eta antsietatea sentitzen ditu (Reyes Pérez eta Reidi, 2015).

Hori dela eta, atxikimendu mota hau duten haurrek estres emozional handia jasaten dute eta beraien kideekin arazo ugari izaten dituzte (Torquati eta Vaszonyi in Reyes Pérez eta Reidi, 2015). Gainera, Lubetzky eta Gilat-ek (2002) burututako ikerketa batek adierazi zuen atxikimendu anbibalentea duten haurrek, segurua dutenekin alderatuz, beldur gehiago izaten dituztela euren bizitzan zehar.

Ainsworth eta besteek (in Casullo eta Liporace, 2005) egindako ikerketari erreparatuz, honako hauek dira atxikimendu anbibalentea zuten haurrek adierazitako jokabide edo ezaugarriak: banandu aurretik deseroso agertzea, ez dira erosotasunezko egoera sortzeko gai, negar egiten dute eta ama itzuli ondoren ez dute jolasten jarraitzeko gaitasunik.

Azkenik, atxikimendu desantolatu/desorientatua duen haurrak, intentsitate handiko beldur eta antsietate-egoeran murgildurik, eraso eta ihes egiteko estrategiak garatzen ditu egoera horri aurre egin ahal izateko. Gainera, ez du atxikimendu-figura ezberdintzen, atxikimendu ezaren itxura ematen $\mathrm{du}$, nahaste, beldur eta kontraesana sentitzen du atxikimendu-figuraren aurrean, negar eta haserrealdi kontrolaezinak izaten ditu eta ez dauka estresari aurre egiteko inongo estrategiarik (Van der Kolk, 2014).

Atxikimendu mota honen inguruko lehen teorizazioak konponbiderik gabeko beldurrarekin erlazionatu ziren, haurrak aurre egiteko gaitasunik ez duen dilema bati aurre egin behar dion egoera bizitzearekin erlazionatuz. Izan ere, bere atxikimendu-figura da beldurra eragin eta, aldi berean, segurtasuna eskaintzen dion pertsona bakarra. Horrelako kasu gehienen atzean guraso tratu txar emaile edota haurraren atxikimendubeharrei erantzuteko gai ez den sentsibilitaterik gabeko kasuren bat egon ohi da (Rodríguez, 2010).

Ainsworth eta besteek (in Casullo eta Liporace, 2005) egindako ikerketan ikusi zen ama itzuli ondoren jokabide desantolatu eta desorientatuak zituela (ibili, lurrera bota, besoak altxa), bere jokabideestrategietan kolapso iragankorra pairatzearen itxura emanez.

Azken hiru mota hauek atxikimendu-asalduraren ondorioz agertzen dira. Atxikimendu-asaldura haurrak 5 urte izan baino lehenago bizitako egoera estresagarriek eragiten dute, bizitzan zehar topatuko dituen egoera sozialetan eragingo duena (Zeanah et al., 2004). Hau 4. taulak erakusten dituen testuinguruetan eman daiteke.

Azalpen honek argi eta garbi adierazten du haurtzaroan ezbehar goiztiarrak pairatzearen eta atxikimenduaren asaldurak pairatzearen arteko erlazioa, kausa-ondorio erlazioa dutela erakutsiz. 
4. taula. Atxikimendu-asaldura eragin dezaketen egoerak

\begin{tabular}{|l|}
\hline Abandonatua edo erakunde batean utzia izan den haurra. \\
\hline $\begin{array}{l}\text { Afektibitate-figura ezberdinekiko aldentze ugari izan dituen } \\
\text { haurra. }\end{array}$ \\
\hline Bere beharrei erantzuten ez dien figura afektiboa duen haurra. \\
\hline Gehiegizko zein gutxiegizko zaintza duen haurra. \\
\hline Ezegonkortasun handiko figura afektiboa duen haurra. \\
\hline Tratu txarrak (abusu psikologikoa, fisikoa edo sexuala). \\
\hline $\begin{array}{l}\text { Bere garapenaren oinarrizko etapetan modu argian bereizitako } \\
\text { erreferentziazko figura afektiborik izan ez duen haurra. }\end{array}$ \\
\hline
\end{tabular}

Iturria: Van der Kolk (2019).

\subsection{Erresilientzia}

Haurtzaroan ezbehar goiztiarrak bizitzeak eragin ditzaketen bizipen traumatikoen aurrean izandako erreakzioa aldakorra, continuum batean eraldatuz, eta modu ezberdinetakoa izan daiteke. Poseck eta besteek (2006) ondorengo erreakzio posibleak eman daitezkeela diote: desoreka, desoreka atzerapena, susperraldia, erresilientzia eta trauma osteko garapena. Kasu honetan, erresilientzia landuko da.

Fisikaren esparrutik datorren erresilientziakontzeptuak materialek talkei aurre egin eta kanpoko indarren aurrean ez deformatzeko duten gaitasunari egiten dio erreferentzia (De Pedro eta Muñoz in Martin de Castro et al., 2016: 158).

Hezkuntzaren munduan bat egiten dute fisikako definizio honekin, aurrera egitera eramaten gaituen dinamika positiboa bezala ulertuta. Hala eta guztiz ere, giza erresilientzia ez da datorkigunari eustera soilik mugatzen, berreraikitzea ahalbidetzen baitu ere. Hori dela eta, erresilientzia pertsona batek lur jota ez gelditzeko eta ezbeharrei aurre eginez (estresa, abusua, galerak eta abandonua edo eguneroko tentsioak) bere burua gainditzeko duen gaitasuna da.

Ondorioz, pertsona erresilienteak zoritxarrean murgildurik edo arrisku-faktoreez inguratuta egon arren, babesezko faktoreak hartu eta egoera horretan hazi eta behar bezala garatzeko gaitasuna du, nahiz eta itxaropen guztiak aurkakoak izan (Noriega et al., 2015).

Melillo-k (2004) adierazten du honako hauek direla erresilientziaren oinarriak, zeintzuen estimulazioaren bitartez ezinbestekoa duten pertsonek erresilientzia gara dezakete: autoestimu sendoa (gainerako oinarrien funtsa da, haurraren behar afektiboak behar bezala erantzun dituen heldu esanguratsu baten zainketaren ondorioz garatzen dena), introspekzioa (norbere buruari galdetu eta erantzun zintzoak ematearen artea da, besteengandik jasotako errekonozimenduaren eraginez garatzen den autoestimuaren arabera), independentzia (norberaren eta arazoak eragiten dituen egoeraren artean limiteak jartzen jakitea bezala definitu izan da, isolamenduan erori gabe distantzia emozional eta fisikoa mantentzea), erlazionatzeko gaitasuna (beste pertsonekin intimitatezko harremanak eraikitzeko gaitasuna. Autoestimuak eragin zuzena du honetan, izan ere, autoestimu baxua izateak autobaztertzea eragin dezake, lotsak eraginda, eta altuegiak errefusa eragin dezake, harrokeria dela eta), iniziatiba (geroz eta eskaera handiagoko zereginei aurre egiteko gogo eta gaitasuna izatea da), umorea (norberaren tragedian kutsu komikoa aurkitzea), sormena (desordena eta kaosetik abiatuz ordena, edertasuna eta helburuak sortzeko gaitasuna. Hausnarketarako gaitasuna du iturburu, jolasaren bitartez lantzen dena haurtzaroan), moralitatea (inguruko pertsona guztien ongizatea desiratu eta gizarteko balioekin konprometitzea. Besteenganako tratu egokien oinarria da) eta pentsamendu kritikorako gaitasuna (aurreko oinarri guztien garapen egokiaren ondorioa $\mathrm{da}$, haurrari pairatzen ari den ezbeharraren jatorri eta ardurak modu kritikoan aztertzea ahalbidetzen diona, batez ere gizartea denean, bere osotasunean, aurre egiten ari den ezbeharra).

\section{Bestalde, Reyes Pérez eta Reidi-ek (2016)} erresilientziaren garapenaren inguruko honako hiru ondorio hauek atera zituen: 1) abandonua edota bestelako ezbeharrak bizi izan dituzten haurrek jokabide erresilienteak adierazten dituzte; 2) erresilientzia ez da soilik banakako gaitasunekin erlazionatzen, ingurune sozial, kultural edo instituzionalarekin izandako interakzioek ere eragina dute; eta 3) ingurune instituzionala (babes-neurrien menpe dauden haurrengan) erresilientziaren garapena sustatzen duen kanpo faktorea da.

Noriega et al. (2015) bat datoz bigarren ondorio horrekin, lan askok erresilientzia faktore pertsonal eta testuingurukoen konbinazioa dela dioen ideiarekin bat egiten dutela diote eta. Hauen ustez, faktore horien konbinazioa da, hain zuzen ere, bizitzan topatzen dituzten ezbeharrei aurre egiteko duten erreminta nagusia.

Gainera, erresilientziaren inguruan egindako lehen ikerketek, "haur erresilientearen" gaitasunengan (autonomia eta autoestimu altua) zentratu zirenak, (Masten eta Garmezy, 1985) ideia hori indartzen dute ere, erresilientziaren garapenean eragiten duten honako hiru faktore daudela adieraziz: 1) haurraren ezaugarriak; 2) familiaren ezaugarriak; eta 3) testuinguru sozialaren ezaugarriak (Werner eta Smith in Iglesias, 2006).

Honela azaltzen ditu Garmezy-k (1993) egoera estresagarri baten aurrean eragiten duten pertsonaren inguruko hiru faktoreak: lehenengoa norbanakoaren izaera izango litzateke, zeinak aktibitate-maila, egoera berrien aurrean hausnartzeko gaitasuna eta gaitasun kognitiboa barnebiltzen ditu, besteak beste. Bigarrenak familiarekin du erlazioa, egoera horri aurre egiteko beharrezkoa den maitasun, kohesio eta helduren baten babesa ematearekin. Hirugarrena, aldiz, laguntza sozialaren erabilgarritasuna izango 
litzateke. Hau modu ezberdinetakoa izan daiteke: amaordea, irakaslea, agentzia edo erakunderen bat, elizako zerbitzuak eta abar.

Zenbait ikerketek eskolak, irakasleak eta eskolako bizipenek erresilientziaren eraikuntzan bete dezaketen papera azpimarratu dute. Izan ere, eskola ikasle guztien (babesgabekoa izan edo ez) garapen integralerako eta erresilientziaren garapenerako testuinguru ezin hobea izan daiteke. Horretarako, aldiz, alderdi kognitiboarekin loturiko irakas/ikas dikotomia alde batera utzi eta ikasle guztiei erlazio positiboak eraikitzeko aukera berdinak (zenbait kasutan bestelako testuinguru sozialetako bizipen negatiboak gainditzen laguntzen dutenak) ematen dizkien benetako komunikazio eremua bilakatzea ezinbestekoa da (Uriarte, 2006).

\section{Ikerketaren helburuak}

Lehenik, marko teorikoaren bidez azterketa bibliografikoa egin eta "haurtzaroko esperientzia gogor goiztiar" kontzeptura hurbilpen bat proposatzea. Kontzeptua bera, atxikimendu- eta erresilientzia-kontzeptuak eskolara gerturatzea mugarri izanik.

Bigarrenik, eremu enpirikoan, gaiaren inguruan jakineko eskola bateko irakasleei galdetzea, honen inguruan irakasleriak dakiena antzeman nahian.

Azkenik, marko teorikoa eskuan eta irakasleek honen inguruan duten jakintzak buruan, gai honetan adituak diren irakasleekin focus group bat antolatu eta eskolan haurtzaroan gatazka goiztiarrak dituzten haurrekin sortzen diren arazoen inguruan eta konponbide posibleen inguruan hitz egitea.

\section{Metodologia}

\subsection{Partaideak}

Baliatuko diren partaide motak bi dira: Gipuzkoako herri bateko ikastolako irakasleak - Haur Hezkuntza $(\mathrm{HH})$, Lehen Hezkuntza (LH) eta Derrigorrezko Bigarren Hezkuntza (DBH) etapetakoak-. Denetara 40 galdetegi banatu dira eta horietarik \% 37,5 ak erantzun du, erantzunen kopurua bera oso esanguratsua izanik.

Eztabaida-taldeko kideak lau dira. Talde hau osatzen dute Euskal Herriko Unibertsitateko irakasleek eta haurtzaroko esperientzia gogor goiztiarrak barnebiltzen dituen egoerekin harreman zuzenak bizi izan dituztenek. $\mathrm{P}_{1}, \mathrm{P}_{2}, \mathrm{P}_{3}$ eta $\mathrm{P}_{4}$ bezala izenpetuko ditugu. Bi irakaslek semeak dituzte abandonatuak, beste batek ama eta hirugarrena bera da abandonatua.

\subsection{Informazioa eskuratzeko baliatutako tresnak}

Metodologia motari dagokionez, kuantitatiboa (galdetegia) zein kualitatiboa (eztabaida-taldea) baliatu dira.

\subsubsection{Galdetegia. Irakasleek erantzundakoa}

Lehenik eta behin, ikastetxe oso bateko irakasleriari galdetegia bideratu zaio Google Forms plataforma erabilita. Horretarako, aurretik baimenak lortu dira eta ondoren egin da inkesta. Galdetegia erantzuteko bi hilabete eman dira eta laginaren \% 37,5ak erantzun du. Galdetegia itxia izan da, baina hainbat galderetan aukera irekiak utzi dira, galdetuek erantzun zabalak eman zitzaten. Hiru ardatzetan hartu du oin galdetegiak. Lehenik jakin nahi izan da noraino ezagutzen duten kontzeptua, bigarrenik, trauma goiztiarrekin izandako esperientziak antzeman nahi izan ditugu; eta, azkenik, eskolak nahiz irakasleek emaniko erantzunak eta gai honen inguruan prestakuntzan nahiz antolakuntzan sentitzen dituzten beharrak eta ahuleziak aipatu dituzte.

\subsubsection{Eztabaida-taldean landu da}

Eztabaida-taldea ikerketaren muinaren inguruko informazio esanguratsua biltzeko pertsona-talde bati egindako elkarrizketa baliatzen duen teknika kualitatiboa da (Martínez Angulo, 2019). Horrela, eztabaida-taldearen helburua gidatutako elkarrizketa baten bitartez datu kualitatiboak eskuratzea da. Estrategia hau erabiltzearen abantailen artean daude testuinguru sozial zehatz bateko datu errealak biltzen dituela, moldagarria dela, balio subjektibo handia duela, emaitzak azkar eskuratzen direla eta kostu baxuak dituela (Krueger in Vizcarra et al., 2009).

Limon eta Crespo-k (in Vizcarra et al., 2009) dioten bezala, eztabaida-taldeko moderatzaileak elkarrizketa animatzeko baliatu dezakeen teknika onenetarikoa eztabaida-gaiarekin erlazionatutako bizipenen inguruko interesa adieraztea, eta jarraian, parte-hartzaileei gaiaren inguruan izandako bizipenez hitz egiteko eskatzea da.

Kasu honetan, eztabaida-taldearen bitartez, partaideek haurtzaroko esperientzia gogor goiztiarrek eragiten dituzten ondorioen eta irakasle gisa egoera horietan eskuartzeko iritziak eta gomendioak azaleratzea bilatu da. Horretarako, aipatutako galdetegian egindako galderen ildoa jarraitu da, irakasleen pertzepzioa eta eztabaidataldekoena alderatu ahal izateko.

Hala eta guztiz ere, jarraitu beharreko ildoa prestatua izan arren, elkarrizketa sasi-egituratua egitea erabaki da, galdera itxien zurruntasunetik ihes egin eta partaideen diskurtsoen ahalmen guztia baliatzeko asmoz. Hortaz, elkarrizketaren ildoa ezarri arren, askatasuna eman zaie solaskideei zehaztutako gaietatik desbideratu eta gidoiaren 
bidez aurreikusitako elkarrizketa berrantolatu eta aberasteko.

\section{Emaitzen interpretazioa}

\subsection{Galdetegian ateratako emaitzen interpretazioa}

Irakasleek ikasleen egoera sozial, ekonomiko eta emozionala ezagutzeari ematen dioten garrantziaren inguruan galdetzean, galdetegia erantzun duten irakasleen \% 93,3ak garrantzia handia ematen dio. Gainerako \% 6,7ak, aldiz, ertaina (ikus 1. grafikoa).

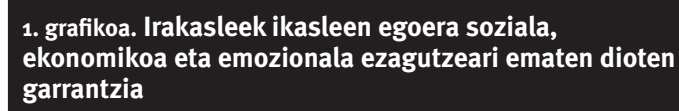

\section{garrantzia}
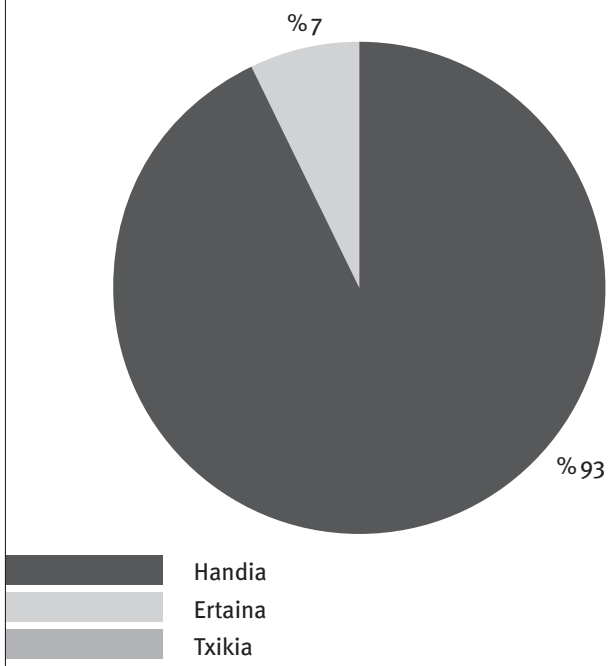

Iturria: Haurtzaroko esperientzia gogor goiztiarren inguruko galdetegia, Gipuzkoako herri bateko ikastola bateko irakasleei zuzendua (egileek egina).

Irakasleek ikasleen inguruko informazioa eskuratzeko baliatzen duten iturria zein den galderari, \% 46,7k “familia eta ikasleak" erantzun dio. Gainerakoek aipatutakoen artean: familia edo ikaslea soilik, burutzen ari den terapiaren arduraduna, gainerako irakasleak, familia eta ikastola, familia eta zuzendaritza, aurreko irakaslea, orientazio-departamentua eta bat ere ez daude (ikus 2. grafikoa).

Ikasleekin duten harremanari dagokionez, \% 73,3ak gertukoa duela dio, ikasleak gustura egotea ahalbidetzen duen konfiantzazko giroa sortzen ahalegintzen direla esanez. Haien helburua ikasleek hor daudela jakitea da, behar duten momentuan gerturatu daitezkeela sentitzea. Gorputz Hezkuntzako irakasleak, aldiz, nahi adina sakontzeko aukerarik ez duela dio, astean saio bakarra izatea izanik muga nagusia. Bestalde, DBHko irakasle batek adin horretako ikasleek distantzia jartzen dutela dio, gai horiei buruz errazago hitz egiten baitute lagunekin, irakasleen aldean behintzat.
2. grafikoa. Irakasleek ikasleen inguruko informazioa eskuratzeko baliatzen duten iturria

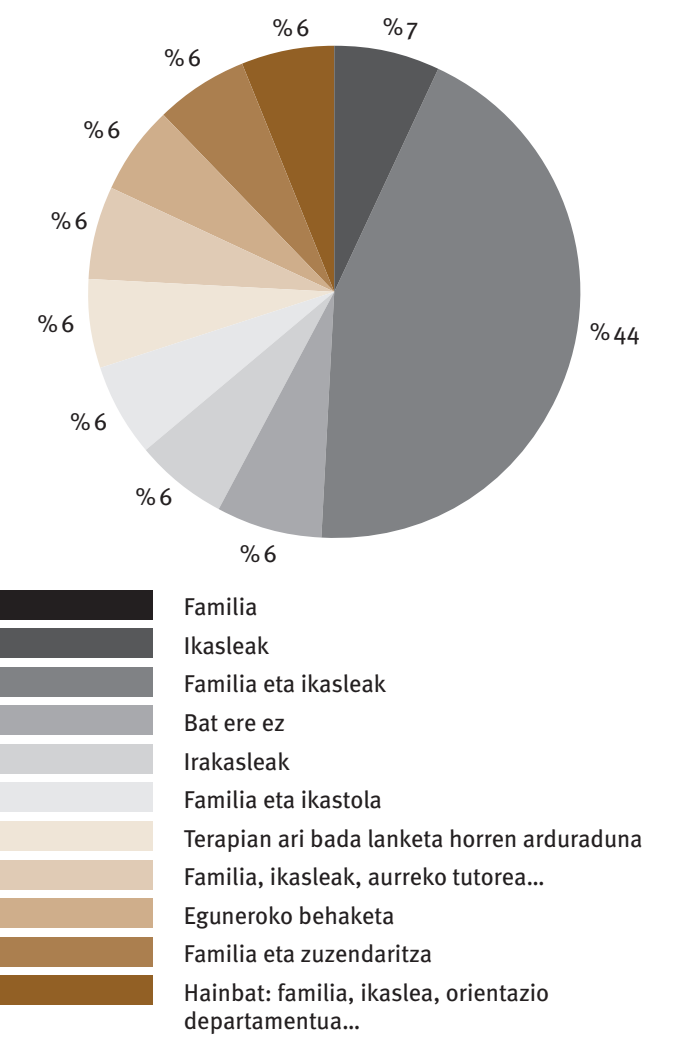

Iturria: Haurtzaroko esperientzia gogor goiztiarren inguruko galdetegia, Gipuzkoako herri bateko ikastola bateko irakasleei zuzendua (egileek egina).

Familiarekin duten erlazioa ezberdina da. \% 6oak gertuko harremana duela dio, \% zoak azalekoa eta $\%$ 10ak, aldiz, ez duela inolako harremanik. Bestalde, eskuratutako informazioari ematen dioten erabilera erabat profesionala dela dio irakasleen \% 10oak, betiere informazio hori ikasleen egoera ezagutzera bideratuta, eta haien ikasketa-prozesuan garapen integrala lortzen saiatzeko.

Irakasle gisa izandako esperientziei kontu hartuz gero, irakasleen \% 10oak izan du egoera zailen bat bizitako edo egun bizi duen ikasleren bat. Egokitu zaizkien kasuak aipatzeko eskatzean: gurasoen banaketa (12), abandonu emozionala (6), familian droga- eta alkohol-kontsumoa eta beste batzuk (5) izan dira gehien aipatutakoak (ikus 3. Grafikoa. Item bakoitzaren alboan agertzen den ehunekoak galdetegia erantzun dutenetatik item hori aukeratu duen ehunekoari egiten dio erreferentzia).

Kasu horiei aurre egitean \% 92,9ak laguntza bilatu izan du, baina \% 7,1ak bere kabuz egin dio aurre egoerari. Bilatutako laguntzari dagokionez, ikastetxeko aholkularia, ikasketa burua, lankideak, berritzegunea eta gizarte-zerbitzuak aipatzen dira.

Ikasleari "benetan behar duen laguntza” emateko gai diren ala ez galdetzean \% 66,7ak ezezkoa eta $\%$ 33,3ak baiezkoa erantzun du, baina "benetan 


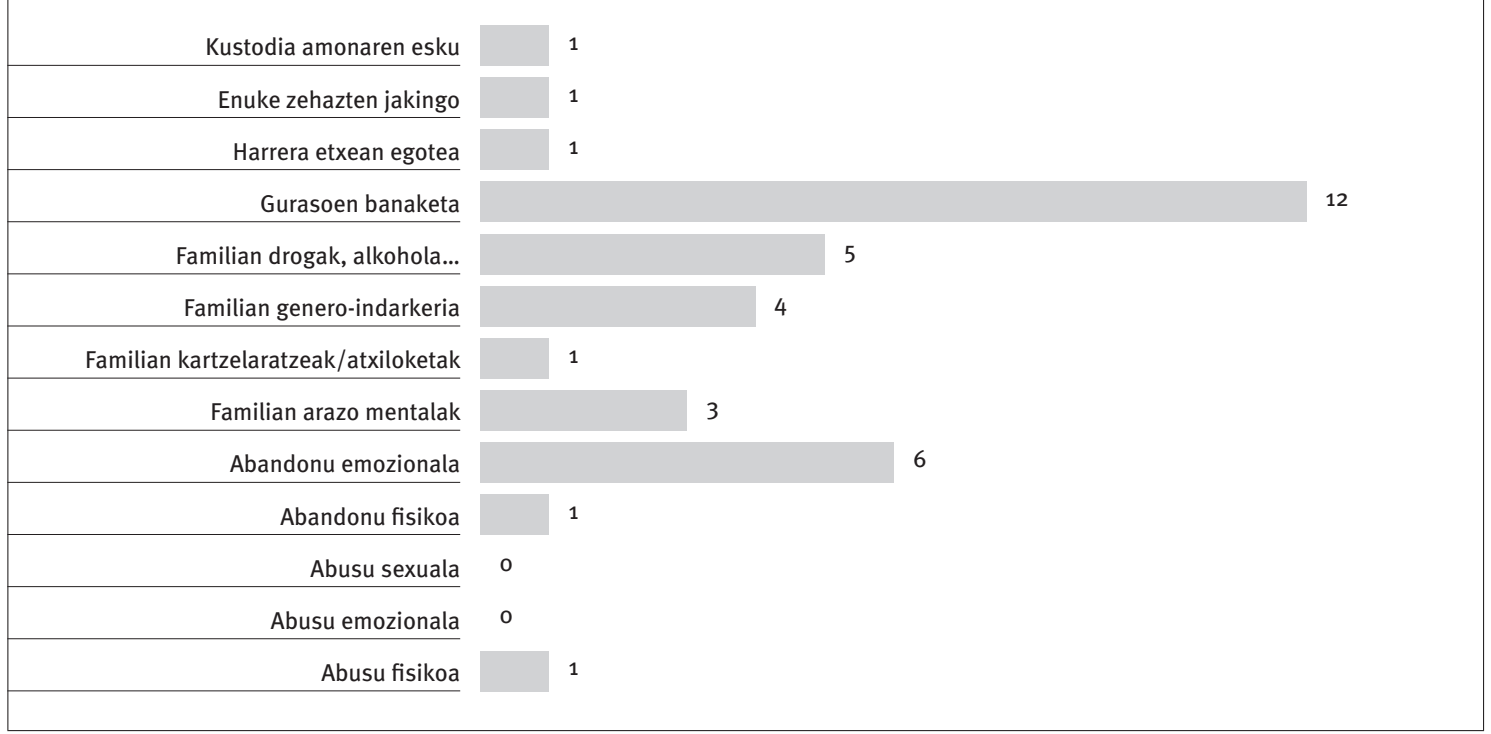

Iturria: Haurtzaroko esperientzia gogor goiztiarren inguruko galdetegia, Gipuzkoako herri bateko ikastola bateko irakasleei zuzendua (egileek egina).

behar duen laguntza" beraientzat zer den galdetzean, erantzun ezberdinak egon dira: laguntza emozionala edo psikologikoa; diagnosia gainditzeko beharrezkoa den laguntza; harekin egotea eta entzutea, edo erresilientzia garatzen laguntzea, besteak beste. Datu hau ere inportantea da, izan ere, inkestako parte-hartzaileetatik \% 37,5ak horrela erantzun baitu. Suposatzen da gaiaren interesetik sorturiko lagina dela, eta \% 66,7aren esanean: ez dakigu nola erantzun ikasleek dituzten esperientzia traumatikoei.

Laguntza hori emateko gai izan ez direnek, izandako gabezi edo zailtasunak egoera detektatzeko prestakuntza eza eta erantzuteko ezaupenik eza nabarmentzen dituzte. Gaiaren inguruko prestakuntza orokorra da faltan bota dutena. Honen harira, \% 86,7-ak gaiaren inguruko prestakuntza jasotzea gustatuko litzaiokeela dio, \% 13,3-ak ezezkoa dioen moduan.

$\%$ 61,5ak ez du prestakuntza-eskaintzarik ezagutzen, bai \% 38,5ak ordea. Eskaintzen artean, ikastetxean bertan jasotakoak (aurtengo ikasturtean Doluaren inguruan jasotakoa, esaterako) eta ikastetxetik kanpoko ikastaroak edo hitzaldiak eta abar aipatzen dira. Horretaz gain, prestakuntzari kasu errealen inguruko lanketa egitea, erresilientzia garatzen laguntzeko teknika edo estrategiak luzatzea eta egoeren detekziorako argibideak ematea eskatuko litzaioke.

Gainera, irakasleen ustez, hezkuntza-komunitatea osatzen duten osagai guztien ardura da (Hezkuntza Saila, ikastetxeko zuzendaritza eta irakasleak) irakasleek egoera horien aurrean behar bezala jokatzeko gaitasuna dutela bermatzea.

Galdetegia egindako ikastetxeak gaiaren inguruan egiten duen lanketa oso ona (\% 40) eta ona (\% 60) dela iruditzen zaie. Indar gune gisara: koordinaziomaila izugarria, berrikuntzen aldeko jarrera eta motibazio handia eta azken urte hauetan gai hauekiko adierazitako sentsibilizazio-maila aipatzen dute. Golden 5 bezalako prestakuntzak oso baliagarri izan direla azpimarratuta. Zuzendaritza-taldearen eta irakasleen arteko inplikazio-maila, azken batean.

Aldiz, hobetu beharrekoen artean, ikastetxeak eskaintzen dituen prestakuntza-saioen kopuru edo maiztasuna handitzea eta egoera hauen aurrean arinago jokatzeko protokolo baten beharra azpimarratzen dute. Hala eta guztiz ere, eskura dauden baliabideekin eta hautatutako bidearekin nahikoa egiten dela irizten diote.

Azkenik, \% 93,3aren iritziz, ikasle bakoitzaren egoera pertsonala ezagutu eta izan ditzaketen zailtasun edota mugak gainditzen laguntzea irakaslearen eginbeharra omen da; ezinbestekoa baita ikasleen ongizate emozionala bermatzea garapen integrala lortu ahal izateko. Aldiz, \% 6,7a ez dator bat ideia horrekin, espezializatutako jendeak egin behar duen lana dela esanez argudiatuta.

\subsection{Eztabaida-taldearen emaitzen interpretazioa}

Eztabaida-taldean lehenik eta behin ikusi nahi izan dugu kontzeptuaren inguruko bidea nondik nora egiten duten gure elkarrizketatuek. Horrela P1-ek eta P2-k semeen abandonua aipatzen dute, eta haietako baten esanean, 20 urte behar izan ditu semearen barrea deskubritzeko: "Barre egitea, poza sentitzea, oso gauza sinplea da, zerbaitek barre eginarazten digu. $\mathrm{Ba}$, nire semeak ez du horretarako motiborik izan, eta eskolak ez dio erakutsi”. P4-k terapiaren bidea hartu zuen amaren abandonua ulertzeko: "Nik uste nire beharra beti izan dela nire amaren abandonu-prozesua 
ulertzea, eta horregatik ikasi nuen psikologia. Gainera, gero eskolan sartu nintzen eta atxikimenduaren lanketa handia egiten aritu naiz". Azkenik, P3-k bizi izandako abandonua eta, batik bat, eskolak betetako erresilientzia-funtzioa goraipatzen du: "Niretzako eskola babeslekua izan da. Etxean neukan egoera oso konplexua, abandonu-egoera oso fuertea. Eskola gabe ez dakit non egongo nintzatekeen. Ez dut uste irakasle bereziak izan nituenik, agian eskolaren urrezko etapa bat bizi izan dut”.

Egoera horretan eskolak izandako jokaeraren inguruan diharduen bigarren galdera honetan, eskolaren aurpegi ona ez da soilik $\mathrm{P}_{3}$-ren kasuan ikusten, $\mathrm{P}_{4}$-k berresten du: "Nire amak ez zuen arazorik izan eskolan, beretzako uharte bat bezala zen. Hortik kanpo, etxean eta kalean, dena zarata zen; ez zeukan kokapenik, ez zeukan lekurik, ez zeukan ahotsik... Ez zeukan ezer. Baina eskolan bai, eskolan bera zen. Ona, txarra; edozer. Baina bera”. P1 eta $\mathrm{P}_{2}$-ren esperientziak, ordea, beste muturrekoak dira. P1-ek dio eskolak ez diela inoiz behar zuten laguntza eman: “Ni, familia bezala, niregana ez dira inoiz hurbildu irakasleak, gu gerturatu izan gara. Guk eman diegu informazioa, guk eraman dizkiegu adituek emandako datu guztiak eta beraiek gure kasua kaxoian sartu dute eta ez diote kasurik egin". P2-k dio oso esperientzia gogorra bizi izan duela eskolarekin: "Oro har irakasleek ez dakite zertaz hitz egiten ari garen, ez dute ideiarik ere gure seme hauek zein ahulak diren eta ezjakintasun horrek ume hauek oso ahulak bihurtzen ditu besteen erasorako".

Eskolaren jokabideaz hausnartzean, P2-k irakasle ibilbidean zehar izandako esperientziaz hitz egiten du eta ikasleei behar eta merezi duten atentzioa eta laguntza eskaintzeko duen ezintasuna azpimarratzen du: "Irakasle bezala, esan behar dut nik ere ez dakidala. Unibertsitatean 100-120 ikasle berri jartzen zaizkidanean aurrean ez dakit nola egin, oso zaila egiten zait jakitea bakoitza non dagoen, baina pozten naiz 6 hilabete eta gero deskubritzen badut zerbait berezia, tutoretzaren batean hitz egiteko aukera izan dudalako edo". P4-k, aldiz, terapeuta gisa lanean aritutako garaian eskolarekin elkarlanean aritzeko zailtasunak izan zituela dio: "Behin eta berriz ikusten nuen umea oso minduta, zaurituta arrazoi ezberdinengatik eta familiak ez zekien oso ondo zer gertatzen zitzaion. Min hori ikusten zuen baina eskolak ez, eta nire harridura zen eskolara deitzean tutoreok ez zutela nirekin hitz egin nahi”.

Hirugarren galderan $\mathrm{P}_{3}-\mathrm{k}$ aipatutako erresilientziaren inguruan hitz egin dute elkarrizketatuek. P1-entzat: "Erresilientzia da beraiek bizitzari gustua hartzea, buelta ematea, indartzea, ahalduntzea. Esatea gaizki pasa arren bizitzan aurrera egingo dut”. P2-k, ordea, irribarreaz hitz egiten du: "Erresilientzia hilda dagoen pertsona horri, trauma izugarria daukan pertsona horri, irribarrea ateratzea da”. P3-k abandonua pairatu izanak eragindako ondorioei aurre egiteko gaitasunarekin erlazionatzen du: "Erresilientziaprozesuak erlazio handia dauka helduak garenean maitatzeko eta lan egiteko dugun gaitasunarekin eta hori da, hain zuzen ere, gure familiarengandik babes nahikoa jaso izan ez dugunok dugun zailtasuna”. Azkenik, $\mathrm{P}_{4-\mathrm{k}}$ bere ama jartzen du erresilientziaeredutzat: "etxe batetik bestera, inork ez du maite, familian oso bakarrik oso abandonatua... Eta berak familia bat eraiki du familia eredu bat izan gabe. Hor dago erresilientzia: eredurik gabe eta, suposatzen da, gaitasunik gabe, familia bat eraiki du".

Gainera, erresilientzia-prozesuak genero kutsu bat duela diote. P1-ek, bere esperientziatik hitz eginez, seme-alaba ulertu eta bizitzen ari den prozesuan laguntzen ahalegindu ohi dena ama dela dio: "Hori amak gehiago egiten du. Nire kasuan, behintzat, egoten edo presentzia hori izaten ahalegindu naiz. Nire senarrak, aldiz, esaten du “ba, baino bueno". Ez da konturatzen". P2-k ere emakume eta gizonezkoen arteko aldea azpimarratzen du: “Gizonezkoek beti errazago ikusten dute. 'Ba, tontokeriak' esaten du[te], baina zuk ikusten duzu ume hori, ez dakiena barre egiten, ume hori sufritzen ari dena. Zuzenean zoaz ama bezala eta pixkanaka bizitzara ekartzen ahalegintzen zara”. P3-k horren arrazoia izan daitekeena proposatzen du: “Emakumeok abantaila batzuk ditugula uste dut, partekatzeko, laguntza bilatzeko eta sareak osatzeko orduan abantailak ditugula”. Bestalde, P4-k sufritzen ari dena mutila edo neska izatearen araberako aldea ere badagoela dio: "mutilak edo gizonezkoak disruptiboak dira. Kanpora ateratzen dute eta oso zigortuak izaten dira. Aldiz, emakumeek gorde egiten dute eta, nahiz eta zentzu batzuetan babestuagoak egon, euren burua zigortzen dute".

Erresilientziarekin amaitzeko, P1-ek haurrei laguntzeko gaitasuna izateko norberak izan behar duenaz hitz egiten du: "Erresilientzia beraiena eta gurea. Autokontzeptu eta autoezagutza prozesua oso luzea da. Horregatik prozesu hori, onartzea, ulertzea eta abar egin behar da eta hazkunde pertsonala egiten da ere. Zuk ez baduzu zure prozesua egiten ezingo diozu besteari lagundu”. P3-k bat egiten du honekin eta terapeuta baten adibidearekin defendatzen du: "ezinezkoa da terapeuta batek terapiarik ez egitea. Norberak bere barrua ezagutu eta landu behar du besteei prozesu hori egiten lagundu ahal izateko".

Ondoren, eskola batek erresilientea izateko behar duenaren inguruan hitz egitean, egoera latza pairatzen ari diren ikasleak detektatzeko beharrezkoa denaz hitz egiten du P3-k: "Irakasleek esaten dutenean detekziorako erremintak nahi dituztela, hor begirada eta intuizio bat garatu behar da, eta hori ez da egiten ikastaro batekin, urteetako lan neketsua da”. P1-ek ere ikuspegi hori partekatzen du: “Ezin duzu kanpotik ikasi, autoikaskuntza da. Sufrimendua duten pertsonekin egonez ikasi behar da”.

Horrela, irakasleek izan beharreko profilaren inguruan hitz egitera ailegatu gara. P1-ek beste lanbideetan bezala irakasle izateko gaitasun batzuk eskatu behar direla defendatzen du: "Ez badituzu, 
garatu, eta ezin badituzu garatu, dedikatu beste zerbaitetara". P3-k prestakuntza pertsonala duten irakasleak behar direla dio: "Profesional edo guraso on bat aurrean duenarekin beldurtzen ez dena da. Horregatik, sentsibilizazioan jarriko nuke indarra, prestakuntza pertsonalean eta sozioafektiboan. Hori dela eta, instituzioek hori kontuan izan behar dute kontratazioak egiterako orduan”. P4-k ere prestakuntza pertsonalari egiten dio erreferentzia: "Autoezagutza klabea da. Irakasleok harremanen bidez eraikitzen dugu ezagutza: ni naiz irakasle moduan nire tresnarik onena edo txarrena". Prozesu zaila dela esan arren, $\mathrm{P}_{2}-\mathrm{k}$ begirada hori lantzen lagundu diona bere semearekin egindako terapia dela dio. Horri esker, sufritzen ari direnengana gerturatzeko modua ikasi du: "Tutoretzara eramatera bultzatzen ditut eta bertan irekitzen dira, lasai-lasai egonda. Izan ere, pertsona horrek zerbait baldin badu, eta kontatu nahi badu, esan egingo du".

Eskolek egin beharrekoarekin jarraituz, hainbat gomendio edo jarraibide proposatzen dituzte elkarrizketatuek. P1-ek bere ustetan oinarrizkoak diren kontzeptuak luzatzen ditu, baina nola landu zehazki ez dakizkienak: "Sareak, taldeka lan egitea, presentzia eta autokontzeptua dira oinarriak". Antzeko zerbait gertatzen zaio P4-ri. Alde batetik, sareen ideiarekin bat egiten du: "sare horien garrantzia oso handia da, elkarlanean egiten baita; ezin dugu guk geuk bakarrik aurrera egin". Eta bestetik, gako batzuk ezagutu arren, ez daki nola jokatu: "Atxikimendua, sentikortasuna, begirada, egotea, entzutea eta maitatzea. Baina dena ezin da didaktifikatu, nahiz eta denak instrukzioa izan behar duela iruditu. Nik ez dakit nola egin behar den”.

P2-k, aldiz, jokabide-aldaketa bat eskatzen die irakasleei zein gizarteari: "Horregatik, nik eskertuko nuke pila bat irakasleen begiradatik eta gizartetik edukitzea sentsibilitate pixka bat min guzti hori ikusteko". Bestalde, $\mathrm{P}_{3}-\mathrm{k}$ bere ustez horrelako prozesuetan laguntzeko altxorra denaz hitz egiten du: "Gertueneko eredua HHko irakaslea da, eta hortik nire ustez asko ikasi daiteke beste etapa batzuetan, bestelako heziketa-harreman bat sortzeko, bestelako begirada bat, bestelako entzuketa bat eta bestelako elkar ezagutze bat....”. Horretaz gain, gizartehezkuntzan baliatu daitezkeen eredu asko ikusten ditu ere.

Hala eta guztiz ere, badakite lan hori aurrera eramateko zenbait oztopo daudela. $P_{3}-k$ hainbat faktore aipatzen ditu: "komunikazioa zaila da, ez dugu elkar ulertzen lehen egunean, ez dago denborarik, kalitatezko denborarik, elkar sentitzeko, elkar begiratzeko. Presaka goaz, beste helburu batzuk ditu hezkuntzak, batez ere DBHk". Hori dela eta, $\mathrm{P}_{1-\mathrm{e}}$ aldaketa orokor bat beharrezkoa dela dio: "Hemen falta da: zer den ulertzea, gogoa, politika bat (dirua) eta irakasleak prestatzea edo prest daudenak bilatzea". Izan ere, $P_{3}-k$ dioen moduan: "gauza asko daude berrikusteko, baina berrikusten ez diren bitartean oso zaila izango da pertsona horiek gizarteko kide bihurtzea".
Baina P3-ren iritziz egoera horretan dauden ikasleei aurrera egiten laguntzea ez da eskolari soilik dagokion eginkizuna eta baliteke eskolari gehiegi eskatzen egotea. Izan ere, bere esperientziak erakutsi dio hezkuntza informaletik ere eragin daitekeela, aurretik aipatutako sareen garrantzia azpimarratuz. Alde batetik, eskola eta herriaren arteko harremanari esker berarekin lanean aritu zen udal psikologoa aipatzen du: "Eskolak jakin izan zuen egoera hori zaintzen eta psikologoaren interbentzioa ez zen zuzena izan (ikastaroen bitartez, etab.). Eta unibertsitatean nabil berarengatik, niretzako erresilientzia tutorea izan da". Bestetik, garai hartan bizitako egoera politikoak herriko gazteen artean eragindako elkarlanaren garrantzia goraipatzen du: "Nik ez nuen amarik baina berdin zitzaidan, herrian ni baino 10 urte zaharragoak ziren beste erreferente batzuek nituen eta niretzat horiek ziren nire irakasleak".

\section{Ondorioak eta eztabaida}

Zehaztutako hiru helburuak bete dira: gaiaren hurbilpena eta haurtzaroko esperientzia gogor goiztiar (Felliti et al., 1988) kontzeptuaren inguruko azalpena aurrera eraman dira bilaketa eta azterketa bibliografikoari esker. Esan behar da kontzeptu hau gurean oso arrotza dela inkestan ikusi den bezala eta irakurketa bibliografikoa egitea ez dela batere lan erraza izan, izan ere, gai honen inguruan gaztelaniaz nahiz euskaraz apenas ez dago ezer. Bigarrenik, irakurketa bibliografikoan landu eta azaldutakoa alderatu eta osatu da ikastetxe jakin bateko irakasleen erantzunekin eta gaiaren inguruan adituak diren Unibertsitateko irakasleen bizipen eta ikuspuntuekin.

Ikastetxeko irakasleen kasuan, adierazgarria izan da banatutako galdetegietatik $\% 35,7 \mathrm{k}$ soilik jaso duela erantzuna. Honek erantzun ez duten irakasleek gaiaren inguruan ezer jakin nahi ez dutela edota beraien eguneroko jarduna aurrera eramaterako orduan baliagarria izango den informazioa eskuratzeko baliorik ez duela iruditzen zaiela pentsatzera eraman gaitzake.

Oraindik eta deigarriago da interes-gabezia hau erantzun duten irakasleek beraien ibilbide profesionalean zehar izandako esperientzia kontuan izanez gero. Izan ere, prebalentzia handia dagoela adierazten dute datuek, baina badirudi galdetegia luzatu den ikastetxeko irakasleen \% 64,3ak ez duela hori ikusten, edo ezikusiarena egiten duela, eta ezer gertatuko ez balitz bezala egiten dutela aurrera.

Bestalde, inkestan jasotako erantzunak ez datoz bat eztabaida-taldean jasotakoarekin. Izan ere, ikastetxeko irakasleen erantzunetan \% 93,3ak euren ikasleen egoera sozial, ekonomiko eta emozionala ezagutzeari garrantzia handia ematen diotela, ikasleekin konfiantzazko eta gertutasunezko harremana dutela eta haien familiekin harreman estua izan ohi dutela adierazita. Baina eztabaidataldeko P1 eta P2 kideek, gurasoak izanik, 
esperientzia erabat aurkakoa azpimarratu dute. Beraiengana gerturatu ez diren irakasleak, enpatia eta laguntzeko gogorik gabekoak aipatzen dituzte. Baliteke galdetegia erantzun ez dutenen gisako irakasleekin topo egin izana edota, askotan gertatzen den bezala, esaten denetik egiten denera alde handia egotea. Edota interes handia izanik prestakuntza eta ezjakintasuna izatea, izan ere $86,7 \%$ ak adierazi du gai hauen inguruan prestakuntza handiagoa izatea gustatuko litzaiokeela.

Honen arrazoia eskolak familiak haurraren garapen integralean duen garrantzia ez duela ezagutzen izan daiteke, eskolaren jarduna osatzen duten higiene ohitura, arau eta jokabide egokiko irizpideez hornitzera soilik mugatuz haren ekarpena. Izan ere, eskolak ez du ezagutzen familiak baliabide pedagogikoen iturri gisa duen papera eta honekin elkarlanean aritzeak duen berebiziko garrantzia. Hori dela eta, eskolak familien errealitate soziokulturalari ateak irekitzeko ezinbestekoa da gizartean errotua dagoen kulturaren inguruan hausnartzea (Rivera eta Milicic, 2006).

Landutako kontzeptuak barnebiltzen dituen egoeraren bat bizitzen ari diren ikasleei "benetan behar duten laguntza” emateko gaitasuna izan dutela adierazi du ikastetxeko irakasleen \% 33,3ak, laguntza hori laguntza emozionala edo psikologikoa, duen diagnosia gainditzeko beharrezkoa den laguntza, berarekin egon eta entzutea edo erresilientzia garatzen laguntzea gisa ulertuz. Kasu honetan, esan beharra dago eztabaida-taldean parte hartu duten adituek laguntzeko modurik hoberena ikasleekin egotea, entzutea, begirada egokiarekin begiratzea eta maitatzea dela diotela ere. Hortaz, bide onetik doazela esan dezakegu eta bat egin dutela \% 33,3arekin. Ikastetxeetako \% 66,7ak ordea azpaimarratu du haurtzaroko esperientzia gogor goiztiarren barnean kokatzen diren kasuen aurrean ez dakiela zer egin. Beraz, erantzun ez dutenak eta ez dakitenak gehituta eskola honetan arazo hau konpontzeko gaitasuna adierazi dutenen kopurua $\% 12,49 k 0 a$ da.

Adituek aipatu duten moduan laguntzeko modu zehatzik ez dagoen arren, autore bakoitzak ikasleari lagundu diezaiokeen jokabide edota baliabideren bat proposatzen du. Witt, Wheeless eta Allen-ek (in García Cabrero, 2009) adierazten dute erlazio positiboak daudela gertutasun eta afektibitatearen artean, eta baita gertutasun, ikaskuntza kognitibo eta arreta eta parte-hartze mailaren artean. Gainera, adituek aipatzen dituzten jokabideen garrantzia azpimarratzen dute Thomas eta besteek gertutasunezko hitzezko zein hitzik gabeko jokabideek eragin positiboa dutela esanda (in García Cabrero, 2009).

Hala eta guztiz ere, laguntzerako orduan zailtasunak izan dituztela eta prestakuntza behar eta nahi dutela dioten arren, adituek diote ez dagoela horretarako errezetarik, ezin dela didaktifikatu. Beraien ustez sufritzen ari diren pertsonekin egonez ikasten da hori eta norberaren ezagutzaren garrantzia azpimarratzen dute. Guztiz bat dator honekin Imbermon (in Arteaga et al., 2015), praktika profesionalaren inguruko hausnarketa eta analisian oinarritutako garapen profesionala ezinbestekoa dela esanez. Zentzu honetan, beraz, irakasleek begirada eta sentsibilitate aldaketa egin behar dutela dirudi, erantzunak kanpoan bilatzeaz utzi eta baliabideak ekinaren ekinaz eskuratuz.

Horretaz gain, irakasleek laguntza bilatu izan dutela dioten arren, terapeuta gisa lanean aritu izan den eztabaida-kideak irakasleengandik errefusatua izan dela adierazi du, askotan beraien eremuan sartzen ari zela iruditu izan zaiela esanez. Jokabide hau berehala aldatu beharrekoa da adituen ustez, ikasleei aurrera egiten laguntzeko ezinbestekoa baita bere inguruan elkarlanean oinarritutako laguntza sarea osatzea, testuinguru formal eta informaleko kideek osatua. Izan ere, laguntzazko sare hauek dira pertenentzia-sentimendua sustatu eta integrazio soziala eragiten dutenak (Huenchuan et al., 2003).

Azkenik, irakasleak eta adituak bat datoz egoera honetan dauden ikasleekin lan egiteko gaitasuna duten irakasleak daudela bermatzea Hezkuntza Sailaren egin beharra delaren ideiarekin. Hortaz, aurretik aipatutako irakasleen sentisibilitate eta begiradaren aldaketaz gain, Hezkuntza Sailak kontratazioen orduan aldaketak egin behar dituela ondorioztatzen da ere, irakasle izateko beharrezkoak diren gaitasunak eta konpromezua dituztenak kontratatuz. Zentzu honetan, Nova-ren (2011) arabera, gaur egungo irakasle batek landuko dituen edukien eta beren didaktikaren, lanbidearen eta bere buruaren inguruko ezagutza eta bere praktikaren inguruan hasunartzeko gaitasuna izan behar ditu.

\section{5. taula. Ondorio sintetikoak}

- Galdekatu den eskolako irakasleariaren kontzeptuarekiko interes faltaren lekuko banatutako galdetegietatik \% 35,7ak soilik erantzun izana.

- Erantzun ez dutenak eta ez dakitenak gehituta eskola honetan arazo hau konpontzeko gaitasuna adierazi dutenen kopurua $\% 12,49$ koa da.

- \% 86,7ak adierazi du landutako kontzeptuaren inguruan prestakuntza handiagoa izatea gustatuko litzaiokeela.

- Adituen esanetan, sufritzen ari diren pertsonekin egonez ikasten da modu naturalean ikaslea laguntzen eta horretarako norberaren ezagutzaren garrantzia ezinbestekoa da.

- Laguntzeko modurik hoberena ikasleekin egotea, entzutea, begirada egokiarekin begiratzea eta maitatzea.

- Erlazio positiboak daude gertutasun eta afektibitatearen artean, eta baita gertutasun, ikaskuntza kognitibo, arreta eta partehartze mailaren artean ere.

- Praktika profesionalaren inguruko hausnarketa eta analisian oinarritutako garapen profesionala oso inportanteak dira sentsibilitatea lantzeko.

- Ikasleei aurrera egiten laguntzeko ezinbestekoa da bere inguruan elkarlanean oinarritutako laguntza sarea osatzea, testuinguru formal eta informaleko kideek osatua.

- Irakasle batek landuko dituen edukien, didaktikaren, lanbidearen, bere buruaren inguruko ezagutza eta bere praktiken inguruan hausnartzeko gaitasuna izan behar ditu.

Iturria: Egileek egina. 


\section{Aipatutako bibliografia}

AMERICAN ACADEMY OF PEDIATRICS (2014): Adverse Childhood Experiences and the Lifelong Consequences of Trauma [https://www. aap.org/en-us/Documents/ttb_aces_ consequences.pdf].

ARRUABARRENA, M.I. eta DE PAÚL, J. (1999): Maltrato a los niños en la familia: evaluación y tratamiento, Madril, Pirámide.

ARTEAGA, A. et al. (2015): "Programa para la mejora de la sensibilidad (PMS) y habilidades de interacción del profesorado de Educación Infantil", Educatio Siglo XXI, 33. bol., 2. zk., 281-302 or.

BARCA, E. (2015): “Análisis del impacto y la alteración de la función cognitiva en niños adoptados y/o víctimas de maltrato, abuso y/o negligencia temprana desde el Modelo PASS del procesamiento de la información" [doktorego tesia], Ourense, Universidad de Vigo.

BARTHOLOMEW, K. (1990): “Avoidance of intimacy: An attachment perspective", Journal of Social and Personal Relationships, 7. bol., 2. zk., 147-178 or.

BARTHOLOMEW, K. eta HOROWITZ, L. (1991): “Attachment styles among young adults: A test of a fourcategory model", Journal of Personality and Social Psychology, 61. bol., 2. zk., 226 or.

BARUDY, J. eta DANTAGNAN, M. (2010): Los desafíos invisibles de ser padre o madre: manual de evaluación de las competencias y la resiliencia parental, Madril, Gedisa.

BLANCO, R. (1999): “La atención a la diversidad en el aula y las adaptaciones del currículo", in MARCHESI, A.; COLL, C. eta PALACIOS, J. (biltz.): Desarrollo psicológico y educación, III. Trastornos del desarrollo y necesidades educativas especiales, Madril, Alianza, 411-437 or.
BOLÍVAR, P. (2017): “Los niños ante la ruptura parental” [gradu amaierako lana], Granada, Universidad de Granada.

BORNSTEIN, M.H.; HAHN, C.S. eta SUWALSKY, J.T.D. (2013): "Language and internalizing and externalizing behavioral adjustment: Developmental pathways from childhood to adolescence", Development and Psychopathology, 25. bol., 3. zk., $857-878$ or.

BRUCE, K.S. (2011): "Bajo rendimiento escolar: una perspectiva desde el desarrollo del sistema nervioso", Revista Médica Clínica Las Condes, 22. bol., 2. zk., 218-225 or.

CANTÓN, J.; CORTÉS, M.R. eta JUSTICIA, M.D. (2002): “Las consecuencias del divorcio en los hijos", Psicopatología Clínica Legal y Forense, 2. bol., 3. zk., 47-66 or.

CASULLO, M.M. eta FERNÁNDEZ LIPORACE, M. (2005): "Evaluación de los estilos de apego en adultos", Anuario de Investigaciones (Buenos Aires), 12. zk., 183-192 or.

CENTERS FOR DISEASE CONTROL AND PREVENTION et al. (2016): About the CDC-Kaiser ACE Study, Centers for Disease Control and Prevention.

CHIU, M. (2010): "Effects of inequality, family and school on mathematics achievement: Country and student differences", Social Forces, 88. bol., 4. zk., $1.645-1.676$ or.

DEL HOYO, P. eta RODRÍGUEZ, L. (2004): “Hijos de padres psicóticos. Revisión bibliográfica: implicaciones preventivas, de apoyo y terapéuticas", Revista de Psicopatología y Salud Mental del Niño y el Adolescente, 4. zk., 99-108 or.

DIRECCIÓN GENERAL DE SERVICIOS PARA LA FAMILIA Y LA INFANCIA (2012): Boletín de Datos Estadísticos 
de Medidas de Protección a la Infancia [2012ko datuak].

DUBE, S., et al. (2001): “Growing up with parental alcohol abuse: Exposure to childhood abuse, neglect, and household dysfunction", Child Abuse \& Neglect, 25. bol., 12. zk., 1.627-1.640 or.

ECHEBURÚA, E. eta CORRAL, P. (2006): "Emotional consequences in victims of sexual abuse in childhood", Cuadernos de Medicina Forense, 43-44. zk., 75-82 or.

ESPAINA (2004): "Ley Orgánica 1/2004, de 28 de diciembre, de Medidas de Protección Integral contra la Violencia de Género", Boletín Oficial del Estado, 313. zk., 42.166-42.197 or.

FELITTI, V. et al. (1988): “Relationship of childhood abuse and household dysfunction to many of the leading causes of death in adults", American Journal of Preventive Medicine, 14. bol., 4. zk., 245-258 or.

FRÍAS, D. et al. (1992): “Estructura familiar y depresión infantil”, Anuario de Psicología, 52. zk., 121-132 or

GARAI, B. et. al. (2019): "Cambiemos la mirada docente ante el alumnado que nadie quiere: de un problema de conducta a un tema de justicia social", in MURILLO, F.J. eta MARTÍNEZ-GARRIDO, C. (koord.), XIX Congreso Internacional de Investigación Educativa [aktak], 1. bol., Madril, Asociación Interuniversitaria de Investigación Pedagógica, $351-356$ or.

GARCÍA CABRERO, B. (2009): "Las dimensiones afectivas de la docencia”, Revista Digital Universitaria, 10. bol., 1. zk., 2-12 or.

GARMEZY, N. (1993): “Children in poverty: Resilience despite risk”, Psychiatry, 56. bol., 1. zk., 127-136 or.

GODDARD, C. (2016): "Adult problems made in childhood”, Children \& Young People Now, 11. zk., 20-22 or.

GÓMEZ MONTES, J.M. (2005): "Pautas y estrategias para entender y atender la diversidad en el aula", Pulso, 28. zk., 199-214 or.

GONZÁLEZ, N.T. (2007): "Síndrome de niño maltratado: variedad negligencia", Revista de la Facultad de Medicina UNAM, 50. bol., 3. zk., 128-130 or.

GONZÁLEZ-TORRES, M.C. eta TOURÓN, J. (1992): Autoconcepto y rendimiento escolar: sus implicaciones en la motivación y en la autorregulación del aprendizaje, Madril, Eunsa.

HERNÁNDEZ, R. eta GRAS, R.M. (2005): "Víctimas de violencia familiar: consecuencias psicológicas en hijos de mujeres maltratadas", Anales de Psicología / Annals of Psychology, 21. bol., 1. zk., 11-17 or.

HUENCHUAN, S. et al. (2003): "Redes de apoyo social de las personas mayores: marco conceptual”, Notas de Población, urtarrila, 35-70 or.

IGLESIAS, E. (2006): “Resiliencia: definición, características y utilidad del concepto", Revista de Psicopatología y Psicología Clínica, 11. bol., 3. zk., $125-146$ or.

IRIBARREN, L. (2010): "Escuela inclusiva y diversidad de modelos familiares", Revista Iberoamericana de Educación, 53. bol., 6. zk., 1-11 or.
JADUE, J.G. (2002): "Factores psicológicos que predisponen al bajo rendimiento, al fracaso y a la deserción escolar", Estudios Pedagógicos (Valdivia), 28. zk., 193-204 or.

JAUREGIZAR, J. (2019): Atxikimendua ulertzen hezkuntzaren ikuspuntutik, Bilbo, Euskara eta Eleaniztasuneko Errektoreordetzaren Sarea.

JIMÉNEZ GRANDE, A. (2016): "Estudio de la negligencia física como predictora de problemas de conducta en menores cordobeses" [master-tesia], Kordoba, Universidad de Córdoba [http://hdl.handle. net/10396/13479].

KING, D. (2002): Parents, children and prison: Effects of parental imprisonment on children, Dublin, Dublin Institute of Technology.

KUMPFER, K.L.; FENOLLAR, J. eta JUBANI, C. (2013): "Una intervención eficaz de mejora de las habilidades familiares para la prevención de problemas de salud en hijos de personas con adicción al alcohol y las drogas", Pedagogía Social. Revista Interuniversitaria, 21. zk., 85108 or.

LARMAN, G. eta AUNGLES, A. (1991): “Children of prisoners and their outside carers: The invisible population", in WEISER, P. eta MCKILLOP, S. (ed.), Women and the Law [konferentzia baten aktak], Canberra, Australian Institute of Criminology.

LÓPEZ, F. et al. (1995): “Prevalencia y consecuencias del abuso sexual al menor en España", Child Abuse \& Neglect, 19. bol., 9. zk., 1.039-1.050 or.

LUBETZKY, O. eta GILAT, I. (2002): "The impact of premature birth on fear of personal death and attachment styles in adolescence", Death Studies, 26. bol., 7. zk., 523-543 or.

MANSO, J.M. (2001): "Variables que intervienen en el abandono físico o negligencia infantil comparativamente con otros tipos de maltrato infantil" [doktore tesia], Badajoz, Universidad de Extremadura.

- (2003): "Estudio sobre las repercusiones lingüísticas del maltrato y abandono emocional infantil", Revista de Logopedia, Foniatría y Audiología, 23. bol., 4. zk., 211-222 or.

- (2004): "Maltrato infantil: características familiares asociadas a situaciones de desprotección al menor", Psychosocial Intervention, 13. bol., 1. zk., 99-115 or.

MARTÍN DE CASTRO, J.M. et al. (2016): “Aportaciones del paradigma de resiliencia a la acción socioeducativa. El caso del centro de menores extranjeros no acompañados Zabaloetxe", Pedagogía Social. Revista Interuniversitaria, 28. zk., 157-168 or.

MARTÍNEZ ANGULO, J. (2019): "La construcción de la identidad de un grupo de deportistas de alto nivel: un estudio de caso" [doktorego tesia], Gasteiz, Euskal Herriko Unibertsitatea.

MASTEN, A. eta GARMEZY, N. (1985): “Risk, vulnerability, and protective factors in developmental psychopathology", in LAHEY, B.B. eta KAZDIN, A.E. (ed.) Advances in Clinical Child Psychology, 8. bol., Boston, MA, Springer, 1-52 or.

MAYBERY, D. et al. (2005): "Children of a parent with a mental illness: Perspectives on need", 
Australian e-Journal for the Advancement of Mental Health, 4. bol., 2. zk., 78-88 or.

MAYNARD, B. et al. (2017): Effects of trauma-informed approaches in schools, Campbell Collaboration. Downloaded October, bol. 6.

MEBARAK, M. et al. (2010): “Una revisión acerca de la sintomatología del abuso sexual infantil., Psicología desde el Caribe, 25. zk., 128-154 or.

MELILLO, A. (2004): "Resiliencia: conceptos básicos" [https://www.ugr.es/ javera/pdf/2-3-AG.pdf].

MURIS, P.; MEESTERS, C. eta VAN DEN BERG, S. (2003): "Internalizing and externalizing problems as correlates of self-reported attachment style and perceived parental rearing in normal adolescents", Journal of Child and Family Studies, 12. bol., 2. zk., 171-183 or.

NAVARRO, R. (2003): "El rendimiento académico: concepto, investigación y desarrollo", Revista Iberoamericana sobre Calidad, Eficacia y Cambio en Educación, 1. bol., 2. zk.

NORIEGA, G.; ANGULO B. eta ANGULO, G. (2015): “La resiliencia en la educación, la escuela y la vida”, Perspectivas Docentes, 58. zk., 42-48 or.

NOVA, A. (2011): "Formación docente: hacia una definición del concepto de competencia profesional docente", Revista Electrónica Interuniversitaria de Formación del Profesorado, 14. bol., 1. zk., $67-80$ or.

OLIVA, A. (2004): “Estado actual de la teoría del apego", Revista de Psiquiatría y Psicología del Niño y del Adolescente, 4. bol., 1. zk., 65-81 or.

ORGILÉS, M. et al. (2008): "Miedos escolares en hijos de padres divorciados y no divorciados", International Journal of Clinical and Health Psychology, 8. bol., 3. zk., 693-703 or.

OSUNA, M.J.; HERRUZO, J. eta MOYA, M.C. (2000): "Estudio de las consecuencias del abandono físico en el desarrollo psicológico de niños de edad preescolar en España", Child Abuse \& Neglect, 24. bol., 7. zk., 911-924 or.

PALACIOS, J.; MORENO, M.C. eta JIMÉNEZ, J. (1995): “Child abuse: concept, types, etiology”, Infancia y Aprendizaje, 18. bol., 71. zk., 7-21 or.

PEREDA, N. (2009): “Consecuencias psicológicas iniciales del abuso sexual infantil", Papeles del Psicólogo, 30. bol., 2. zk., 135-144 or.

- (2010): "Consecuencias psicológicas a largo plazo del abuso sexual infantil”, Papeles del Psicólogo, 31. bol., 2. zk., 191-201 or.

PERRY, B. et al. (1995): “Childhood trauma, the neurobiology of adaptation, and 'use dependent' development of the brain: How 'states' become 'traits'”, Infant Mental Health Journal, 16. bol., 4. zk., 271-291 or.

POON, E. et al. (2000): “Intellectual, cognitive, and academic performance among sons of alcoholics during the early school years: Differences related to subtypes of familial alcoholism", Alcoholism. Clinical and Experimental Research, 24. bol., 7. zk., 1.0201.27 or.

POSECK, B.V.; CARBELO, B. eta VECINA, M.L. (2006): "La experiencia traumática desde la psicología positiva: resiliencia y crecimiento postraumático", Papeles del Psicólogo, 27. bol., 1. zk., 40-49 or.

REYES PÉREZ, V. eta REIDI, L.M. (2015): “Apego, miedo, estrategias de afrontamiento y relaciones intrafamiliares en niños", Psicología y Salud, 25. bol., 2. zk., 91-101 or.

RIVERA, M. eta MILICIC, N. (2006): "Alianza familia-escuela: percepciones, creencias, expectativas y aspiraciones de padres y profesores de enseñanza general básica”, Psykhe (Santiago), 15. bol., 1. zk.,119-135 or.

ROBAINA, G. (2001): "El maltrato infantil”, Revista Cubana de Medicina General Integral, 17. bol, 1. zk., 74-80 or.

ROBERTSON, O. (2007): El impacto que el encarcelamiento de un(a) progenitor(a) tiene sobre sus hijos, saila: Mujeres en la Cárcel e Hijos de Madres Encarceladas, Ginebra, Quaker United Nations Office.

ROBLEDO-RAMÓN, P. (2016): “Factores tipológicos y estructurales de la familia y rendimiento académico de los alumnos. Revisión de estudios empíricos", in Castejón Costa, J.L. (koord.), Psicología y educación: presente y futuro, Asociación Científica de Psicología y Educación, 2.888-2.894 or.

RODRÍGUEZ, A. (2010): “El apego. Más allá de un concepto inspirador", Revista de la Asociación Española de Neuropsiquiatría, 30. bol., 108. zk., 581-595 or.

ROSA-ALCÁZAR, A.I.; SÁNCHEZ-MECA, J. eta LÓPEZ-SOLER, C. (2010): "Tratamiento psicológico del maltrato físico y la negligencia en niños y adolescentes: un meta-análisis", Psicothema, 22. bol., 3. zk., 627-633 or.

RUPPERT, F. (2016): Trauma precoz: el embarazo, el parto y los primeros años de vida, Barcelona, Herder.

RUTTER, M. (1986): “Parental mental disorder as a psychiatric risk factor", Psychiatric Epidemiology, 6. zk., 647-663 or.

SACKS, V.; DAVID, M. eta MOORE, M.A. (2014): Adverse Childhood Experiences: National and State-level Prevalence, saila: Research Brief, Child Trends.

SCHAFFER, H.R. eta EMERSON, P.E. (1964): “The development of social attachments in infancy", Monographs of the Society for Research in Child Development, 1-77 or.

SCHOENBORN, C.A. (1991): "Exposure to alcoholism in the family: United States, 1988”, Advance Data, 205. zk.

SEPÚLVEDA, A. (2006): "La violencia de género como causa de maltrato infantil", Cuadernos de Medicina Forense, 43-44. zk., 149-164 or.

SOLER, C. (2008): “Las reacciones postraumáticas en la infancia y adolescencia maltratada: el trauma complejo", Revista de Psicopatología y Psicología Clínica, 13. bol., 3. zk. 159-174 or.

SONKIN, D. (2005): "Attachment theory and psychotherapy", The California Therapist, 17. bol., 1. zk., 68-77 or.

ULLOA, F. (1996): "Violencia familiar y su impacto sobre el niño", Revista Chilena de Pediatría, 67. bol., 4. zk., 183-187 or. 
URIARTE, J. (2006): “Construir la resilencia en la escuela”, Revista de Psicodidáctica, 11. bol., 1. zk., 7-24 or.

VALDÉS, A. et al. (2011): "Efectos del divorcio de los padres en el desempeño académico y la conducta de los hijos", Enseñanza e Investigación en Psicología, 16. bol., 2. zk., 295-308 or.

VAN DER KOLK, B. (2014): El cuerpo lleva la cuenta. Cerebro, mente y cuerpo en la superación del trauma, Barcelona, Eleftheria.

-(2019): “Entrevista a Bessel Van Der Kolk: 'Hay personas traumatizadas que no son consciente de ello"” [Silvia Díez-ek egindakoa], Cuerpo y Mente, maiatzaren 5a [https://www.cuerpomente. com/entrevistas/como-el-trauma-afecta-alcerebro-y-la-vida-entrevista-bessel-van-derkolk_4558].

VIZCARRA, M.T.; MACAZAGA, A.M. eta REKALDE, I. (2009): Las necesidades y valores de las niñas ante la competición en el deporte escolar, Bilbo, UPV/Euskal Herriko Unibertsitateko Argitalpen Zerbitzua.

ZEANAH, C. et al. (2004): "Reactive attachment disorder in maltreated toddlers", Child Abuse \& Neglect, 28. bol., 8. zk., $877-888$ or. 